\title{
Characterization of Pro-ACTH/Endorphin-Derived Peptides in Rat Hypothalamus
}

\author{
Ronald B. Emeson and Betty A. Eipper \\ Department of Neuroscience, The Johns Hopkins University School of Medicine, Baltimore, Maryland 21205
}

The proteolytic processing pattern of pro-ACTH/endorphin in rat hypothalamus is similar to the pattern in the pars intermedia; peptides the size of $\beta$-endorphin, $\gamma$-lipatropin $(\gamma$-LPH), corticotropin-like intermediate lobe peptide (CLIP), $\alpha$-melanotropin $(\gamma-\mathrm{MSH})$, joining peptide, and glycosylated $\gamma_{3}-\mathrm{MSH}$ all represent predominant end products. Equimolar amounts of $\beta$-endorphin-, $\alpha$-MSH-, CLIP-, $\gamma$-LPH-, and joining peptiderelated immunoreactivity are found in hypothalamic extracts ( 3 pmol per hypothalamus). Although the proteolytic processing pattern in the hypothalamus is similar to that in the pars intermedia, a tissue-specific posttranslational processing pattern was detected. Ion-exchange analysis of $\beta$-endorphin-sized immunoreactive material from hypothalamic extracts resolves three major forms, corresponding to $\beta$-endorphin(1-31), $\beta$-endorphin(1-27), and $\beta$-endorphin(1-26). The $\alpha$ - $N$-acetylated forms of endorphin represent less than $10 \%$ of the total $\beta$-endorphin immunoreactivity. Analyses of hypothalamic $\alpha$-MSHsized molecules with acetyl- and amide-directed $\alpha$-MSH antisera suggest that hypothalamic $\alpha$-MSH is fully amidated, but largely not $\alpha-N$-acetylated. Fractionation by reverse-phase highperformance liquid chromatography (HPLC) confirms that $>85 \%$ of the $\alpha$-MSH immunoreactivity corresponds to ACTH(113) $\mathrm{NH}_{2}$ or its sulfoxide, and less than $10 \%$ corresponds to $\alpha$-MSH $\left[\alpha-N\right.$-acetyl-ACTH(1-13) $\left.\mathbf{N H}_{2}\right]$ or its sulfoxide. Isoelectric focusing demonstrates that 83-93\% of hypothalamic CLIP is phosphorylated. Isoelectric focusing suggests that the majority of the hypothalamic $\gamma$-LPH-sized immunoreactive material is indistinguishable from $\gamma$-LPH synthesized by pituitary melanotropes. The minor extent of $\alpha-N$-acetylation of $\alpha$-MSH and $\beta$-endorphin, the limited carboxyl-terminal proteolysis of $\beta$-endorphin, and the extensive phosphorylation of CLIP represent major differences between the posttranslational processing patterns of pro-ACTH/endorphin in the hypothalamus and pars intermedia.

Adrenocorticotropin (ACTH) and $\beta$-lipotropin ( $\beta$-LPH) are synthesized as parts of a larger common precursor molecule [proACTH/endorphin or pro-opiomclanocortin (POMC)], which is posttranslationally processed, in a tissue-specific manner, to yield differing end products in the anterior and intermediate lobes of the pituitary. The co- and posttranslational modifications involved in the processing of this $30 \mathrm{kDa}$ precursor protein include defined and ordered proteolysis, glycosylation, phosphorylation, $\alpha-N$-acetylation and $\alpha$-amidation (Bennett et al., 1982;

\footnotetext{
Received May 20, 1985; revised Aug. 12, 1985; accepted Aug. 23, 1985.

We are grateful to Henry Keutmann for quantitative amino acid analyses of purified rat $\gamma_{3}$-MSH and joining peptide, and to Dick Mains for many enlightening scientific discussions and critical reading of the manuscript. This work was supported by DA-00266, DA-00098, and the McKnight Foundation.

Correspondence should be addressed to Ronald B. Emeson, Department of Neuroscience, The Johns Hopkins University School of Medicine, $725 \mathrm{~N}$. Wolfe Street, Baltimore, MD 21205.

Copyright (c) 1986 Society for Neuroscience $0270-6474 / 86 / 030837-13 \$ 02.00 / 0$
}

Browne et al., 1981a, b; Douglass et al., 1984; Eipper and Mains, 1980, 1982; Krieger et al., 1980; Rudman et al., 1979; Seidah and Chretien, 1981; Zakarian and Smyth, 1982a, b).

Extensive immunohistochemical mapping studies utilizing antisera raised against several pituitary ACTH/endorphin-derived peptides have characterized a large number of neuronal pathways containing antigenic determinants of the ACTH/endorphin system throughout the mammalian brain (Bloom et al., 1980; Joseph, 1980; Oliver and Porter, 1978; Pelletier, 1979; Schwartzberg and Nakane, 1982; Watson et al., 1978; Zimmerman et al., 1978). Although immunoreactive fibers are found in many regions of the forebrain and brain stem, there is general agreement that positively staining cell bodies are located exclusively in the arcuate nucleus of the hypothalamus and the dorsal caudal medulla in the region of the nucleus of the solitary tract (Khachaturian et al., 1983; Romagnano and Joseph, 1983; Schwartzberg and Nakane, 1983).

The structure of the single gene that codes for pro-ACTH/ endorphin within the rat genome (Drouin and Goodman, 1980; Drouin et al., 1983) suggests that any differences that exist between ACTH/endorphin-derived peptides from multiple tissues are the result of tissue-specific posttranslational processing rather than the result of expression of two different genes. Recent studies have demonstrated that, at the level of gel filtration, the processing of pro-ACTH/endorphin-derived peptides in rat hypothalamus more closely resembles the pattern for proteolytic processing in the pars intermedia than in the pars distalis, with both $\alpha$-melanotropin ( $\alpha$-MSH) and $\beta$-endorphin-sized material representing the predominant end products (Barnea et al., 1982; Dennis et al., 1983a; Gramsch et al., 1980; Loh et al., 1980; Orwoll et al., 1979); a summary of the nomenclature for proACTH/endorphin-derived peptides is shown in Figure 9.

In the intermediatc lobc of the pituitary, $\alpha$-MSH-like material has been shown to exist in three distinct forms differing in their degree of acetylation. Although $\alpha-N, O$-diacetyl- $\alpha$-MSH represents the major form of $\alpha$-MSH synthesized by rat pituitary melanotropes (Browne et al., 1981a; Glembotski, 1982; Rudman et al., 1979), there is disagreement over the acetylation state of hypothalamic $\alpha$-MSH-like material (Evans et al., 1982; Geis et al., 1984; Loh et al., 1980; O’Donohue et al., 1981).

Previous studies have shown that the major forms of $\beta$-endorphin in the rat intermediate pituitary are the $\alpha-N$-acetylated derivatives of $\beta$-endorphin( $1-26)$ and $\beta$-endorphin $(1-27)$, whereas the major form produced by the anterior lobe corticotropes is $\beta$-endorphin(1-31) (Akil et al., 1981; Bennett et al., 1983; Eipper and Mains, 1981; Weber et al., 1981; Zakarian and Smyth, 1982a, b). There is still considerable controversy, however, over the extent of $\alpha-N$-acetylation (Weber et al., 1981 ; Zakarian and Smyth, 1982a, b) and carboxyl-terminal proteolysis (Dennis et al., 1983a, b; Liotta et al., 1984; Zakarian and Smyth, 1982a, b) of $\beta$-endorphin in the rat brain.

Previous studies on the posttranslational processing of corticotropin-like intermediate lobe peptide (CLIP) by rat pituitary 
melanotropes have demonstrated that, in addition to the proteolytic cleavages that produce CLIP from ACTH, there are further modifications to which CLIP is subjected, including phosphorylation, $N$-linked glycosylation, and removal of the carboxyl-terminal phenylalanine residue (Bennett et al., 1982; Eipper and Mains, 1982). Previous studies on the biochemical characterization of hypothalamic CLIP have demonstrated multiple peaks of CLIP-related immunoreactivity upon reversephase (RP) HPLC analysis, suggesting the occurrence of posttranslational modifications similar to those occurring in the pars intermedia (Liotta and Krieger, 1983a; Smith et al., 1982; Turner et al., 1983).

The demonstration of ACTH/endorphin-derived molecules in multiple tissues, with the potential of posttranslational modification into products both similar to and different from those elaborated by the anterior and intermediate pituitary lobes, has raised a number of fundamental questions with regard to the chemical nature, biosynthetic pathway, regulation, and function(s) of these peptide products in the different tissues in which they can be found. Since the various peptide products derived from a singlc precursor molecule are released in a coordinated fashion (Liston and Rossier, 1984; Mains and Eipper, 1979; Tager et al., 1975), and each may interact independently with an appropriate target tissue or modulate the effects of another peptide product with such a target tissue (Farese et al., 1983; O'Donohue et al., 1981; Pedersen et al., 1980; Scheller et al., 1984; Walker et al., 1980), a coordinated study on the quantitation and biochemical characterization of hypothalamic proACTH/endorphin-derived peptides was undertaken.

\section{Materials and Methods}

\section{Tissue extraction and sample preparation}

Adult male Sprague-Dawley rats (125-250 gm) were used for all experiments. The animals were decapitated and the whole brains were rapidly removed. Hypothalamic tissue ( $\sim 25 \mathrm{mg}$ per hypothalamus) was excised and homogenized by hand in 5 volumes (wt/vol) of $1 \%$ trifluoroacetic acid, $1 \mathrm{M} \mathrm{HCl}, 5 \%$ formic acid, and $1 \% \mathrm{NaCl}$ (Bennett et al., 1978 ) by means of a conical glass homogenizer with ground-glass pestle. The boundaries of the hypothalamic fragment extended from the anterior margin of the preoptic area to the anterior border of the mammillary bodies. Extracts were frozen and thawed twice and centrifuged at $1500 \times \mathrm{g}$ for $15 \mathrm{~min}$ at $4^{\circ} \mathrm{C}$ to remove insoluble material. The supernatants were removed and the pellets were reextracted by resuspension in $1-2 \mathrm{ml} \mathrm{TFA} / \mathrm{HCl} / \mathrm{HCOOH} / \mathrm{NaCl}$ and then centrifugation; the supernatants were pooled.

Tissue extracts were cycled five times onto a $\mathrm{C}_{18}$ Sep-Pak cartridge (Waters Associates), washed with $20 \mathrm{ml} 0.1 \%$ trifluoroacetic acid and eluted with $4 \mathrm{ml} 80 \%$ acetonitrile in $0.1 \%$ trifluoroacetic acid (Bennett et al., 1981b); $1 \mathrm{mg}$ BSA was added to the Sep-Pak eluate as a carrier protein. The tissue extracts were dried under reduced pressure after addition of 2-mercaptoethanol (1\%).

\section{Gel filtration}

For gel filtration using Sephadex G-75 (40-120 $\mu \mathrm{m})$, tissue extracts were redissolved in $50 \%$ acetic acid containing $5 \% 2$-mercaptoethanol; the Sephadex G-75 column $(0.9 \times 58 \mathrm{~cm})$ was eluted with $10 \%$ formic acid, $20 \mu \mathrm{g} / \mathrm{ml}$ bovine serum albumin, and $0.1 \% 2$-mercaptoethanol (Eipper and Mains, 1982; Glembotski, 1982). For HPLC gel filtration, tissue extracts were redissolved in $250 \mu \mathrm{l}$ of $32 \%$ acetonitrile containing $0.1 \%$ trifluoroacetic acid; the samples were applied to a Bio-Sil TSK-400 column $(7.5 \times 300 \mathrm{~mm})$ connected in series to a Bio-Sil TSK-250 $(7.5 \times$ $300 \mathrm{~mm})$ and a Bio-Sil TSK-125 $(7.5 \times 300 \mathrm{~mm})$ column (Bio-Rad). The columns were eluted with $32 \%$ acetonitrile in $0.1 \%$ trifluoroacetic acid (Bennett et al., 1981b; Eipper et al., 1983) at a flow rate of $1 \mathrm{ml} /$ min. The elution times of several standard proteins and synthetic peptides were determined by monitoring absorbance at $220 \mathrm{~nm}$. Recoveries, determined by the use of various ${ }^{3} \mathrm{H}$-labeled pro-ACTH/endorphinderived peptides purified from primary cultures of rat intermediate pituitary or mouse corticotropic tumor cells (Keutmann et al., 1981), were in excess of $90 \%$.

\section{Radioimmunoassays}

Radioimmunoassays for $\beta$-endorphin utilized antiserum Danielle [specific for $\beta$-endorphin(10-19); Mains and Eipper, 1979]. Radioimmunoassays for $\alpha$-MSH utilized antiserum Ann [a general ACTH(1-13) assay; Glembotski, 1982], antiserum Annette [an amide-directed $\alpha$-MSH assay; Eipper et al., 1983], and antiserum Patti [an acetyl-directed $\alpha$ MSH assay; Eipper et al., 1983]. Radioimmunoassays for CLIP [ACTH(18-39)] utilized antiserum Kathy [specific for ACTH(34-39); Mains and Eipper, 1983]. Antiserum Kathy showed less than $0.2 \% \mathrm{M}$ cross-reactivity with ACTH(7-38) compared with either hACTH(1-39) or ACTH(18-39), demonstrating the necessity of the carboxyl-terminal phenylalanine residue for full cross-reactivity. Radioimmunoassays for $\gamma$-LPH utilized antiserum Henrietta; as reported previously for rat pituitary (Eipper and Mains, 1979), immunoassays for rat hypothalamic $\gamma$-LPH-related peptides utilizing mouse $\beta$-lipotropin as a radiolabeled trace and standard showed nonparallel displacement.

In order to quantitate the relative levels of $\gamma$-LPH-related molecules in gel filtration fractions, the amount of each fraction to be assayed was varied so that the actual amount of ${ }^{225} \mathrm{I}-\beta_{\mathrm{m}}-\mathrm{LPH}$ (mouse $\beta$-lipotropin) displaced by each sample was similar. All assays were performed as previously described.

Radioimmunoassays for $\gamma$-MSH-relatcd peptides were performcd with a 1:800 dilution of antiserum Gertrude (Eipper et al., 1983), using purified AtT-20 16K fragment (Keutmann et al., 1979) as a radiolabeled trace and purified rat intermediate pituitary $\gamma_{3}-\mathrm{MSH}$ as a standard. Assays were performed in $50 \mathrm{~mm}$ sodium phosphate, $\mathrm{pH} 7.6$, containing $0.025 \%$ Triton X-100; the final assay volume was $200 \mu \mathrm{l}$, and incubations were carried out for $18 \mathrm{hr}$ at $4^{\circ} \mathrm{C}$ with approximately $10,000 \mathrm{cpm}$ of ${ }^{125}$ I-labeled peptide per tube. Double-antibody immunoprecipitation was used to separate bound from free peptide. Under these conditions, the assay had a midpoint of approximately $200 \mathrm{fmol}$; maximum net binding was $25 \%$, and nonspecific binding was $0.5 \%$. Antiserum Gertrude demonstrated approximately $70 \%$ molar cross-reactivity with purified AtT-20 16K fragment and less than $0.01 \%$ molar cross-reactivity with $\alpha$-MSH, CLIP, purified mouse $\beta$-LPH, purified rat joining peptide, human ACTH, and camel $\beta$-endorphin.

Radioimmunoassays for amidated joining peptide were performed with a 1:4000 dilution of antiserum Jamie; the antiserum was generated by injection of a female New Zealand White rabbit with a modified synthetic carboxyl-terminal fragment of rat-joining peptide coupled with glutaraldehyde to BSA [D-Tyr-Pro-Glu-Pro-Ser-Pro-Arg-Glu-NH ${ }_{2}$ or D-Tyr-joining peptide(12-18) $\mathrm{NH}_{2}$; Vega Biotechnologies]. Assays were performed as described, using D-Tyr-joining peptide $(12-18) \mathrm{NH}_{2}$ as standard and trace (Eipper and Mains, unpublished observations). The joining peptide assay demonstrated approximately $70 \%$ molar crossreactivity with purified rat-joining peptide and less than $0.01 \%$ molar cross-reactivity with joining peptide(12-19) (Vega Biotechnologies), $\beta$ endorphin, $\alpha-\mathrm{MSH}, \mathrm{ACTH}$, CLIP, purified rat $\gamma_{3}-\mathrm{MSH}$, purified mouse $\beta$-LPH, and equine $\beta$-MSH.

\section{$R P-H P L C$ analysis of $\alpha-M S H$-related material}

$\alpha$-MSH-sized material obtained by chromatography on Sephadex G-75 or gel filtration HPLC was dried under reduced pressure, resuspended in $0.1 \%$ trifluoroacetic acid, and analyzed on a $\mathrm{C}_{18} \mu$ Bondapak column (Waters Associates; $4 \times 250 \mathrm{~mm}$ ) using the trifluoroacetic acid/acetonitrile system of Bennett et al. (1981b); specific elution conditions are indicated in the figure legends. Synthetic marker peptides were purchased from Bachem. The elution positions of synthetic standard peptides were determined in parallel RP-HPLC analyses by monitoring absorbance at $220 \mathrm{~nm}$.

\section{Ion-exchange analysis of $\beta$-endorphin-related material}

$\beta$-Endorphin-sized material obtained by chromatography on Sephadex G-75 or gel filtration HPLC was dried under reduced pressure and analyzed by ion-exchange chromatography on Sulfopropyl-Sephadex (SP-Sephadex-C25-120), as previously described (Mains and Eipper, 1981; Zakarian and Smyth, 1979). A trace amount of ${ }^{3} \mathrm{H}$-labeled $\beta$ endorphin(1-31) obtained from AtT-20 cells (Mains and Eipper, 1981) was included in each sample as an internal marker. For immunoassays, fractions were dried under reduced pressure and dissolved in $0.1 \mathrm{M}$ Tris$\mathrm{HCl}$ [Tris(hydroxymethyl)aminomethane] containing $2 \mathrm{mg} / \mathrm{ml} \mathrm{BSA}, \mathrm{pH}$ 8.0.

Whole hypothalamic tissue extracts or $\beta$-endorphin-sized material 
from hypothalamic extracts were dried under reduced pressure, redissolved with $10 \mathrm{~mm}$ ammonium formate, $\mathrm{pH} 2.5$, in $30 \%$ acetonitrile, and analyzed by ion-exchange HPLC on a Bio-Sil TSK CM-2-SW cation-exchange column $(4.6 \times 250 \mathrm{~mm}$; Bio-Rad $)$ equilibrated with 35 $\mathrm{mm}$ ammonium formate, $\mathrm{pH} 2.5$, in $30 \%$ acetonitrile. Samples were eluted with a 60 min linear gradient to $326 \mathrm{~mm}$ ammonium formate, $\mathrm{pH} 2.5$, in $30 \%$ acetonitrile; the flow rate was $0.7 \mathrm{ml} / \mathrm{min}$. Buffers were prepared from a stock solution of $5 \mathrm{M}$ formic acid titrated to $\mathrm{pH} 2.5$ with ammonium hydroxide. The elution positions of six synthetic $\beta$-endorphin standards (Peninsula) were determined by monitoring absorbance at $280 \mathrm{~nm}$ (Fig. 1). As shown in Figure 1, the $\beta$-endorphin-related peptides are eluted primarily on the basis of their charge at $\mathrm{pH} 2.5$ (charge given in brackets): acetyl- $\beta_{\mathrm{h}}$-endorphin(1-26) $[+3], \beta_{\mathrm{h}}$-endorphin $(1-26)[+4]$, acetyl- $\beta_{c}$-endorphin $(1-27)[+4], \beta_{c}$-endorphin $(1-27)$ $[+5]$, acetyl- $\beta_{c}$-endorphin $(1-31)[+6]$, and $\beta_{c}$-endorphin $(1-31)[+7]$. The fact that acetyl- $\beta_{c}$-endorphin $(1-27)[+4]$ and $\beta_{\mathrm{h}}$-endorphin $(1-26)[+4]$ are separated by this fractionation procedure indicates that separation is not based solely on charge. Camel and rat $\beta$-endorphin(1-31) have identical amino acid sequences (Bennett et al., 1983; Drouin and Goodman, 1980; $\mathrm{Li}$ and Chung, 1976); $\beta$-endorphin(1-26) is identical in humans, rat, and camel (Chang et al., 1980). Application of trace amounts of ${ }^{3} \mathrm{H}$-labeled AtT-20 $\beta$-endorphin(1-31) $(<0.05 \mathrm{pmol})$ to this ion-exchange system, in the absence of tissue extract or carrier protein, resulted in recovery of only $46 \%$ of the radioactivity. Inclusion of $2 \mathrm{ng}(0.6 \mathrm{pmol})$ of synthetic $\beta_{c}$-endorphin $(1-31)$ along with the ${ }^{3} \mathrm{H}$-labeled sample increased recovery of radioactivity to levels in excess of $80 \%$. In analyses of hypothalamic extracts, recoveries of $\beta$-endorphin-related immunoreactivity were greater than $70 \%$.

Oxidation of the methionine residue in $\beta$-endorphin can occur during the course of tissue extraction and subsequent biochemical analyses (Houghton and Li, 1979; Mains and Eipper, 1981). Thus, we assayed the effect of methionine oxidation on elution of peptides from the ionexchange (IEX)-HPLC column. Synthetic $\beta_{\mathrm{c}}$-endorphin(1-31) and acetyl- $\beta_{\mathrm{h}}$-endorphin(1-26) were oxidized with hydrogen peroxide and analyzed on the IEX-HPLC column both separately and together with nonoxidized peptide standards. Although the elution positions of oxidized $\beta_{c}$-endorphin $(1-31)$ and acetyl- $\beta_{\mathrm{h}}$-endorphin $(1-26)$ were earlier than those of their corresponding nonoxidized counterparts (data not shown), the altered retention times were not sufficiently different to interfere with peptide identification.

\section{Oxidation of $\alpha-M S H$ standards}

Synthetic $\alpha$-MSH $\left[\alpha-N\right.$-acetyl-ACTH(1-13) $\left.\mathrm{NH}_{2}\right]$ and $\mathrm{ACTH}(1-13) \mathrm{NH}_{2}$ were suspended separately $(1 \mathrm{mg} / \mathrm{ml})$ in $1 \mathrm{M}$ acetic acid to which 200 $\mu \mathrm{l} / \mathrm{ml}$ of $30 \%$ hydrogen peroxide was added (O'Donohue et al., 1981). The reaction was allowed to proceed for $30 \mathrm{~min}$ at room temperature, and then an equal volume of $0.1 \%$ trifluoroacetic acid was added. The reaction mix was then injected into the $\mathrm{C}_{18} \mu$ Bondapak column, using the trifluoroacetic acid/acetonitrile system of Bennett et al. (1981b). Fractions containing methionine sulfoxide ${ }^{4}-\alpha-\mathrm{MSH}$ ([Met(O)]- $\left.\alpha-\mathrm{MSH}\right)$ and $[\mathrm{Met}(\mathrm{O})]-\mathrm{ACTH}(1-13) \mathrm{NH}_{2}$ were pooled, dried under reduced pressure, and dissolved in $1 \mathrm{~mm} \mathrm{HCl}$.

\section{Isoelectric focusing}

$\gamma$-Lipotropin and CLIP-sized immunoreactive material obtained by chromatography on Sephadex G-75 were dried under reduced pressure; samples were dissolved in $5 \mathrm{~mm}$ acetic acid containing $0.01 \%$ Triton $X-100$ and applied to a 1 or $2 \mathrm{~mm}$ layer of Sephadex IEF resin (Pharmacia) containing 2\% ampholytes (pH 2.5-5.0; Eipper and Mains, 1982). Electrophoresis was allowed to proceed for 16 to $20 \mathrm{hr}$ at $600 \mathrm{~V}$ to ensure focusing of peptides. Bands of resin $(0.7 \mathrm{~cm})$ were scraped from the glass plate and eluted as indicated in the figure legends. Resin particles were removed by eluting the resin in disposable columns (Evergreen). Samples from one lane of the isoelectric focusing gel were suspended in $2 \mathrm{ml}$ of water to determine the $\mathrm{pH}$ profile.

\section{Enzymatic digestions}

Digestions with alkaline phosphatase were performed for $4.5 \mathrm{hr}$ at $37^{\circ} \mathrm{C}$ in $0.1 \mathrm{M} \mathrm{NH}_{4} \mathrm{HCO}_{3}$ containing $0.5 \mathrm{mg} / \mathrm{ml} \mathrm{BSA}$ and $0.2 \mathrm{units} / \mathrm{ml}$ alkalinc phosphatase (Sigma type III, $42 \mathrm{U} / \mathrm{mg}$ ); the reaction was stopped by lyophilization (Eipper and Mains, 1982). Digestions with TPCK-trypsin (Worthington, $236 \mathrm{U} / \mathrm{mg}$ ) were carried out as previously described (Eipper and Mains, 1977). When alkaline phosphatase digestions were to

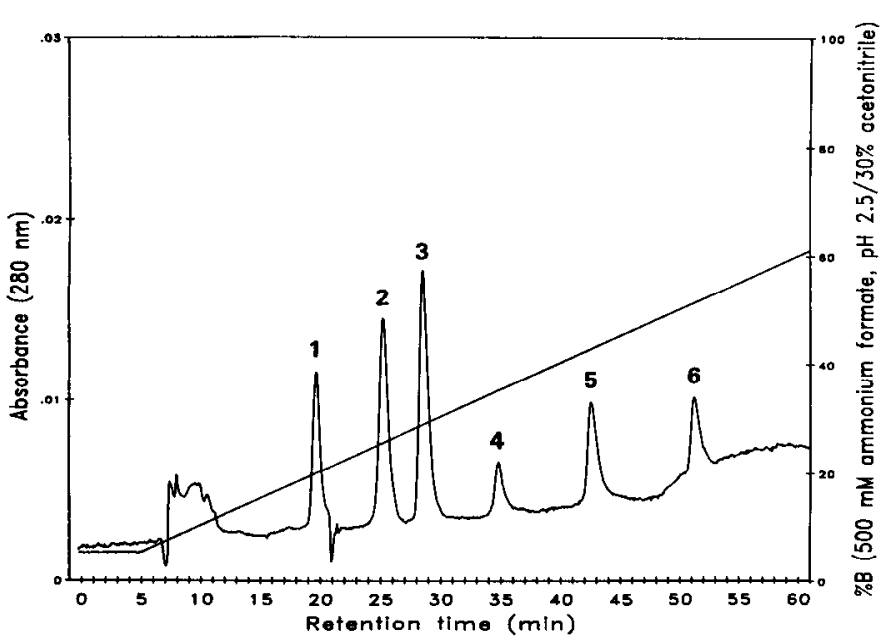

Figure 1. Ion-exchange HPLC of synthetic $\beta$-endorphin-related peptides. Fifteen micrograms of synthetic $(1)$ acetyl- $\beta_{\mathrm{h}}$-endorphin $(1-26)$, (2) acetyl- $\beta_{c}$-endorphin(1-27), (3) $\beta_{\mathrm{h}}$-endorphin(1-26), (4) $\beta_{\mathrm{c}}$-endorphin $(1-27),(5)$ acetyl $-\beta_{\mathrm{c}}$-endorphin $(1-31)$, and (6) $\beta_{\mathrm{c}}$-endorphin $(1-31)$ were mixed and then separated on a Bio-Sil TSK CM-2-SW cationexchange column as described in Materials and Methods. The retention times of the standards were determined by monitoring absorbance at $280 \mathrm{~nm}$. The identities of the peaks were determined by a series of analyses in which the peptides were chromatographed both separately and together.

be carried out subsequently, trypsin was inactivated by addition of phenylmethylsulfonyl fluoride $(0.3 \mathrm{mg} / \mathrm{ml})$ and incubation at $37^{\circ} \mathrm{C}$ for $15 \mathrm{~min}$.

\section{Results}

\section{Gel filtration analyses of hypothalamic extracts}

At the level of gel filtration, the processing of pro-ACTH/endorphin in rat hypothalamus has previously been shown to resemble the pattern in the pars intermedia more closely than the pattern in the pars distalis (Barnea et al., 1982; Dennis et al., 1983a, b; Gramsch et al., 1980; Liotta and Krieger, 1983a, b; Loh et al., 1980). However, in none of these previous studies was there an attempt to quantitate and simultaneously correlate the processing of a number of the peptides derived from the pro-ACTH/endorphin precursor, including $\alpha$-MSH, $\beta$-endorphin, CLIP, $\gamma$-LPH, $\gamma$-MSH, and joining peptide. Hypothalamic extracts were subjected to size fractionation utilizing Sephadex $\mathrm{G}-75$; fractions were analyzed by radioimmunoassay with antisera directed against several ACTH/endorphin antigenic determinants.

Three peaks of amino-terminal ACTH-related immunoreactivity were detected with a general ACTH(1-13) immunoassay (Fig. 2, top; Table 1). The predominant end product was $\alpha$-MSHsized. Two additional species with apparent molecular weights of 16,000 and $6500 \mathrm{Da}$ represented less than 3 and $5 \%$ of the total ACTH-related immunoreactivity, respectively. ACTHsized material represented approximately $2 \%$ of the total ACTHrelated immunoreactivity; while pro-ACTH/endorphin-sized material was not detectable.

Three molecular weight forms of $\beta$-endorphin-related immunoreactivity were detected utilizing an antiserum directed against $\beta$-endorphin(10-19) (Fig. 2, top; Table 1). The $\beta$-endorphin-sized material represented the predominant end product, with minor amounts of both pro-ACTH/endorphin- and $\beta$-LPH-sized material (Fig. 2, top; inset). As can be seen in Figure 2 (top), approximately equimolar amounts of ACTHand $\beta$-endorphin-related material were found $(3.4 \pm 0.3 \mathrm{pmol} /$ hypothalamus; $n=6$ ).

Two major peaks of carboxyl-terminal, ACTH-related im- 
Figure 2. Gel filtration analysis of hypothalamic extracts. Tissue extracts from adult male rat hypothalami ( 17 to 48 hypothalami per extract) were fractionated on Sephadex G-75 as described in Materials and Methods. Aliquots from $1 \mathrm{ml}$ column fractions were analyzed by radioimmunoassay. Top, General amino-terminal ACTH-related peptides ( $\square$ ) and $\beta$-endorphin-relat-

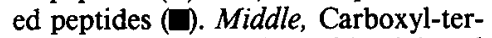
minal ACTH-related peptides (O) and $\gamma$-LPH-related peptides $(\mathrm{O})$. Bottom, Joining peptide-related molecules (A) and $\gamma$-MSH-related peptides $(\Delta)$. Recoveries for all peptides ranged between 84 and $117 \%$. Data are expressed as $\mathrm{fmol} /$ fraction/hypothalamus. Arrows mark the elution positions of either ${ }^{3} \mathrm{H}$ labeled peptides obtained from a mouse corticotropic tumor cell line (AtT-20) or primary cultures of rat neurointermediate lobe and ${ }^{125}$ I-labeled synthetic peptides.

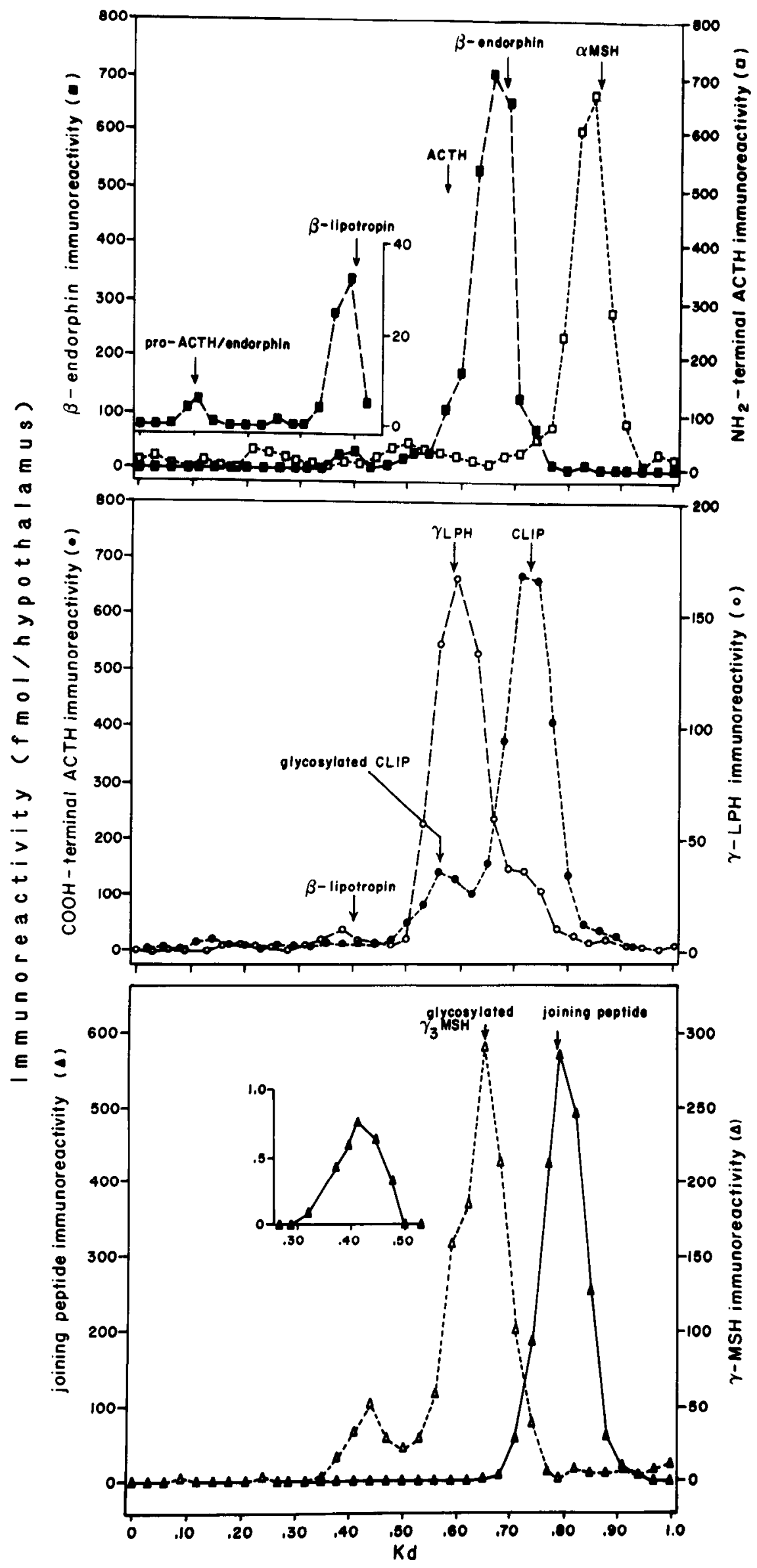


Table 1. Molecular weight distribution of hypothalamic pro-ACTH/endorphin-derived peptides

\begin{tabular}{|c|c|c|c|c|}
\hline Radioimmunoassay & Product & $K_{\mathrm{d}}$ & $\begin{array}{l}\text { Apparent } \\
M_{r}\end{array}$ & $\begin{array}{l}\text { Total } \\
\text { immuno- } \\
\text { reactivity } \\
(\%)\end{array}$ \\
\hline \multirow[t]{5}{*}{ Amino-terminal ACTH } & Pro-ACTH/endorphin & 0.09 & 26,000 & n.d. ${ }^{a}$ \\
\hline & & 0.22 & 16,000 & 3 \\
\hline & & 0.47 & 6500 & 5 \\
\hline & ACTH & 0.56 & 4600 & 2 \\
\hline & $\alpha$-MSH & 0.87 & 1600 & 90 \\
\hline \multirow[t]{3}{*}{$\beta$-Endorphin } & Pro-ACTH/endorphin & 0.09 & 26,000 & 1 \\
\hline & $\beta$-Lipotropin & 0.38 & 8800 & 4 \\
\hline & $\beta$-Endorphin & 0.63 & 3500 & 95 \\
\hline \multirow[t]{3}{*}{ Carboxyl-terminal ACTH } & $\begin{array}{l}\text { ACTH biosynthetic } \\
\text { Intermediate }\end{array}$ & 0.14 & 21,000 & 2 \\
\hline & Glycosylated CLIP & 0.56 & 4600 & 20 \\
\hline & CLIP & 0.72 & 2500 & 80 \\
\hline \multirow[t]{3}{*}{$\gamma$-Lipotropin } & $\beta$-Lipotropin & 0.39 & 8500 & 4 \\
\hline & $\gamma$-Lipotropin & 0.59 & 4100 & 80 \\
\hline & & 0.72 & 2500 & 12 \\
\hline \multirow[t]{2}{*}{ Joining peptide } & & 0.39 & 8500 & 1 \\
\hline & Joining peptide & 0.79 & 1900 & 98 \\
\hline \multirow[t]{2}{*}{$\gamma$-MSH } & & 0.44 & 7100 & 12 \\
\hline & Glycosylated $\gamma_{3}-\mathrm{MSH}$ & 0.65 & 3300 & 83 \\
\hline
\end{tabular}

The data presented represent a summary of the Sephadex G-75 gel filtration analyses shown in Figure 2. Data are expressed as percentage of total immunoreactivity recovered for a given radioimmunoassay. The distribution coefficient $\left(K_{0}\right)$ is defined as $\left(V_{e}-V_{0}\right) /\left(V_{t}-V_{0}\right)$, where $V_{e}$ represents the elution volume of a given molecule, and $V_{t}$ and $V_{0}$ represent the total and void volumes, respectively.

${ }^{a}$ n.d. $=$ Not detected.

munoreactivity (Fig. 2, middle; Table 1), corresponding to the molecular weights of CLIP [ACTH(18-39)] and glycosylated CLIP, were detected. Whereas the elution position of ACTH is identical to that of glycosylated CLIP, the relatively small amount of ACTH detected with the amino-terminal ACTH assay (Fig. 2 , top), demonstrates that most of the material eluting in this region represents glycosylated CLIP. The percentage of hypothalamic CLIP-related immunoreactive material that corresponds to a glycosylated CLIP-sized molecule is identical to that found for CLIP synthesized in the rat intermediate pituitary (Bennett et al., 1982; Eipper and Mains, 1982). A minor peak eluted in the region of ACTH biosynthetic intermediate, representing less than $2 \%$ of the total ACTH-related immunoreactivity. The antiserum used in this analysis does not cross-react with pro-ACTH/endorphin or CLIP-related peptides lacking the carboxyl-terminal phenylalanine residue. The total amount of carboxyl-terminal ACTH-related immunoreactivity was equimolar to that found for amino-terminal ACTH and $\beta$-endorphin-related material (Fig. 2, top).

Two peaks of $\gamma$-LPH-related immunoreactivity, corresponding to the molecular weights of $\beta-\mathrm{LPH}$ and $\gamma-\mathrm{LPH}$, were detected (Fig. 2, middle; Table 1). An additional shoulder of $\gamma$-LPHrelated immunoreactivity, with an apparent molecular weight of 2500 , was also detected. This suggests the occurrence of further limited proteolytic processing of hypothalamic $\gamma$-LPH-related immunoreactive material. Although precise quantitation of rat $\gamma$-LPH-related immunoreactivity is not possible because of the species specificity of the assay, the percentage of $\beta$-LPHsized molecules, compared with total immunoreactivity, was the same whether the $\gamma$-LPH or $\beta$-endorphin immunoassay was used. If one equates the amount of $\beta$-LPH-sized material per hypothalamus detected by the $\gamma$-LPH (Fig. 2, middle) and $\beta$-en- dorphin (Fig. 2, top) assays, the total amount of $\gamma$-LPH-related material per hypothalamus is equimolar to the total amount of $\beta$-endorphin-related material per hypothalamus.

The amino-terminal 94 is composed of amino acids of proACTH/endorphin, a cystine-rich region at the extreme amino terminus, a region referred to as $\gamma_{3}-\mathrm{MSH}$ in the middle, and a joining or "hinge" peptide region at the extreme carboxyl terminus (Drouin and Goodman, 1980; Nakanishi et al., 1979). The carboxyl terminus of rat-joining peptide contains a potential amidation site (-Glu-Gly-Lys-Arg-), and amidated joining peptide has been identified in extracts of human pituitary (Seidah et al., 1981). In hypothalamic extracts, one major peak, corresponding to the size of rat-joining peptide $(1883 \mathrm{Da})$, was detected with an immunoassay specific for amidated joining peptide (Fig. 2, bottom; Table 1); a minor component eluted with a $K_{\mathrm{d}}$ of 0.39 (inset). Similar analyses with a general joining peptide immunoassay (Eipper and Mains, unpublished data) resulted in an identical gel filtration profile; similar amounts of immunoreactive material were detected with both the general and amide-specific joining peptide assays, suggesting that the joining peptide-sized immunoreactive material is largely $\alpha$-amidated. The total amount of joining peptide-related immunoreactivity was roughly equimolar to that of other ACTH/endorphin-derived peptides (Fig. 2, top, middle).

Analyses with an antiserum directed against $\gamma$-MSH detected two peaks of $\gamma$-MSH-related immunoreactivity (Fig. 2, bottom; Table 1) corresponding to the elution positions of glycosylated $\gamma_{3}-\mathrm{MSH}$ and of a molecule with an apparent molecular weight of $7100\left(K_{d}=0.44\right)$. In three separate analyses, the species of $K_{\mathrm{d}} 0.44$ constituted an average of $18 \%$ of the total $\gamma$-MSHrelated immunoreactivity. The molecular weight difference between the species of $K_{\mathrm{d}} 0.39$ detected with the joining peptide 
Figure 3. Gel filtration analysis of hypothalamic extracts using modification-specific $\alpha-\mathrm{MSH}$ antisera. Tissue extracts from 38 adult male rat hypothalami were fractionated on Sephadex G-75 as described in Materials and Methods. Aliquots $(50-300 \mu l)$ were analyzed by radioimmunoassay utilizing a general amino-terminal $\mathrm{ACTH}$ assay (O), an amide-directed $\alpha$-MSH assay $(O)$, and an acetyl-directed $\alpha$-MSH assay $(\mathbf{\Lambda})$. Arrows mark the elution positions of either ${ }^{3} \mathrm{H}$-labeled peptides obtained from a mouse corticotropic tumor cell line (AtT-20) or ${ }^{125}$ I-labeled synthetic peptides. Recovery of general amino-terminal ACTH-related immunoreactivity was $90 \%$.

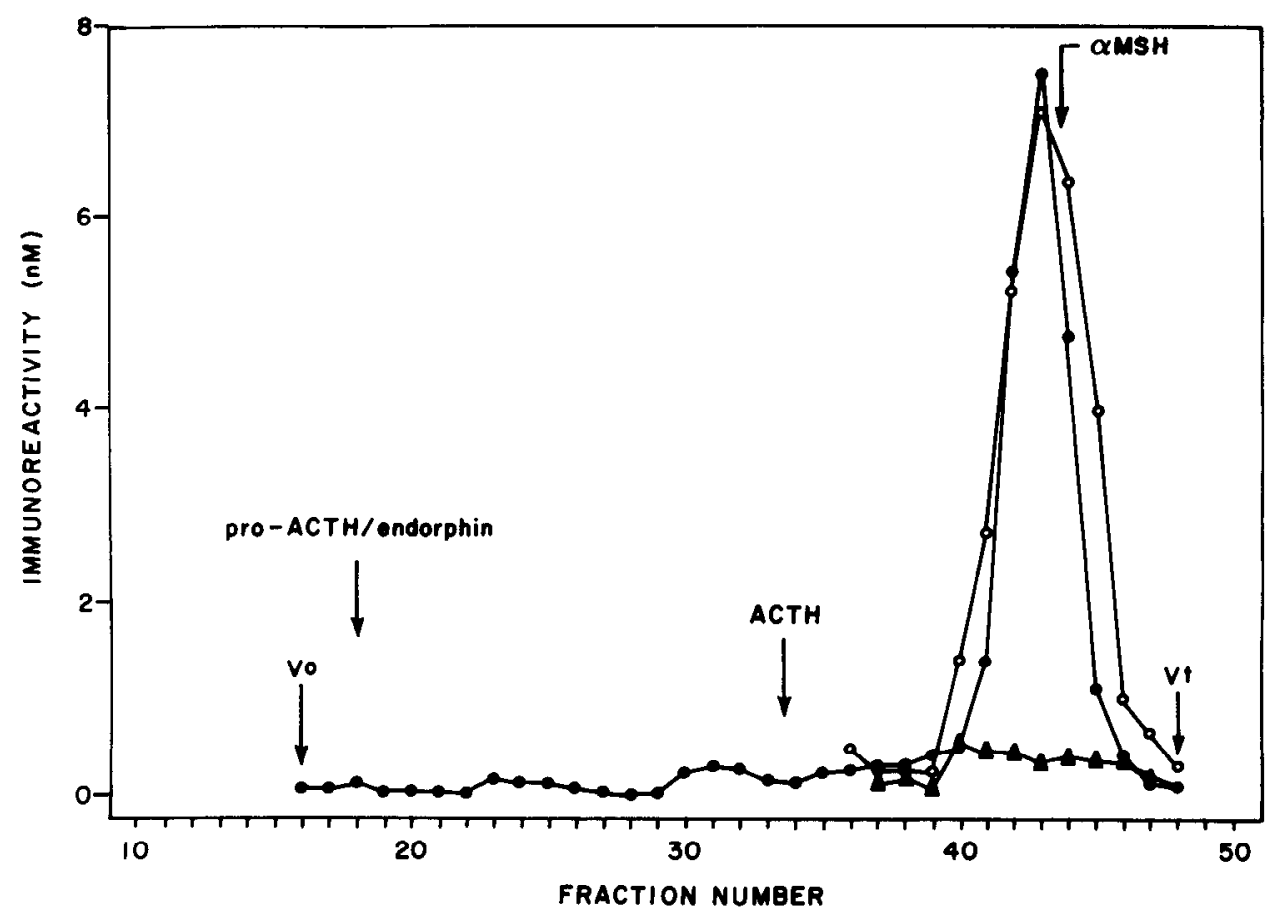

immunoassay and that of $K_{\mathrm{d}} 0.44$ detected with the $\gamma_{3}$-MSH assay roughly corresponds to the molecular weight of joining peptide. The gel filtration profiles obtained with both the $\gamma$ MSH and joining peptide immunoassays were identical to those found for rat pars intermedia (data not shown). Previous studies have demonstrated that 50 to $70 \%$ of the N-terminal fragment synthesized by pituitary melanotropes is glycosylated pro-ACTH/ endorphin(1-74), the remainder being cleaved to form glycosylated Lys- $\gamma_{3}-$ MSH and pro-ACTH/endorphin(1-49) (Seger and Bennett, 1984).

\section{Characterization of $\alpha$-MSH-sized material}

Although earlier studies reported the presence of significant amounts of authentic $\alpha$-MSH $\left[\alpha-N\right.$-acetyl-ACTH $\left.(1-13) \mathrm{NH}_{3}\right]$ in whole brain extracts (Loh et al., 1980; O'Donohue et al., 1981), more recent studies have reported the presence of exclusively desacetyl- $\alpha$-MSH [ACTH(1-13) $\mathrm{NH}_{2}$ ] in extracts of whole brain (Evans et al., 1982) and extracts of rat hypothalamus (Dennis et al., 1983a, b; Evans et al., 1982; Geis et al., 1984; Liotta et al., 1984; Smith et al., 1982; Turner et al., 1983). Three $\alpha$-MSH antisera directed against different $\alpha$-MSH antigenic determinants were used for initial analysis of hypothalamic extracts fractionated by gel filtration (Fig. 3). The general amino-terminal ACTH antiserum demonstrated the expected peak of $\alpha$-MSH-sized immunoreactive material, representing $85 \%$ of the total ACTH-related immunoreactivity (similar to Fig. 2, top). When the $\alpha$-MSH-sized material was analyzed with an amidedirected $\alpha$-MSH antiserum, similar amounts of immunoreactive material were detected. An acetyl-directed $\alpha$-MSH antiserum detected only $13 \%$ as much immunoreactive material as the
Figure 4. Reverse-phase HPLC analysis of hypothalamic $\alpha$-MSH-sized material. A pool of $\alpha$-MSH-sized material $\left(K_{d} 0.79-0.91\right)$ from extracts of 26 adult male rat hypothalami was analyzed on a Waters $\mathrm{C}_{18} \mu$ Bondapak column equilibrated with $4 \%$ acetonitrile in $0.1 \%$ trifluoroacetic acid. Peptides were eluted with a linear gradient from 4 to $24 \%$ acetonitrile in $0.1 \%$ trifluoroacetic acid over $10 \mathrm{~min}$, followed by a linear gradient from 24 to $48 \%$ acetonitrile in $0.1 \%$ trifluoroacetic acid over $50 \mathrm{~min}$. For immunoassays, aliquots $(200 \mu \mathrm{l})$ of $1 \mathrm{ml}$ fractions were analyzed with a general amino-terminal ACTH assay (1), an amide-directed $\alpha-\mathrm{MSH}$ assay $(O)$, and an acetyl-directed $\alpha$-MSH assay ( $(\boldsymbol{\Lambda})$. $A r$ rows mark the elution positions of synthetic $\alpha$-MSH-related peptides, which were determined in a parallel RP-HPLC analysis by monitoring absorbance at $220 \mathrm{~nm}$. Recovery of general aminoterminal ACTH immunoreactivity was $94 \%$.

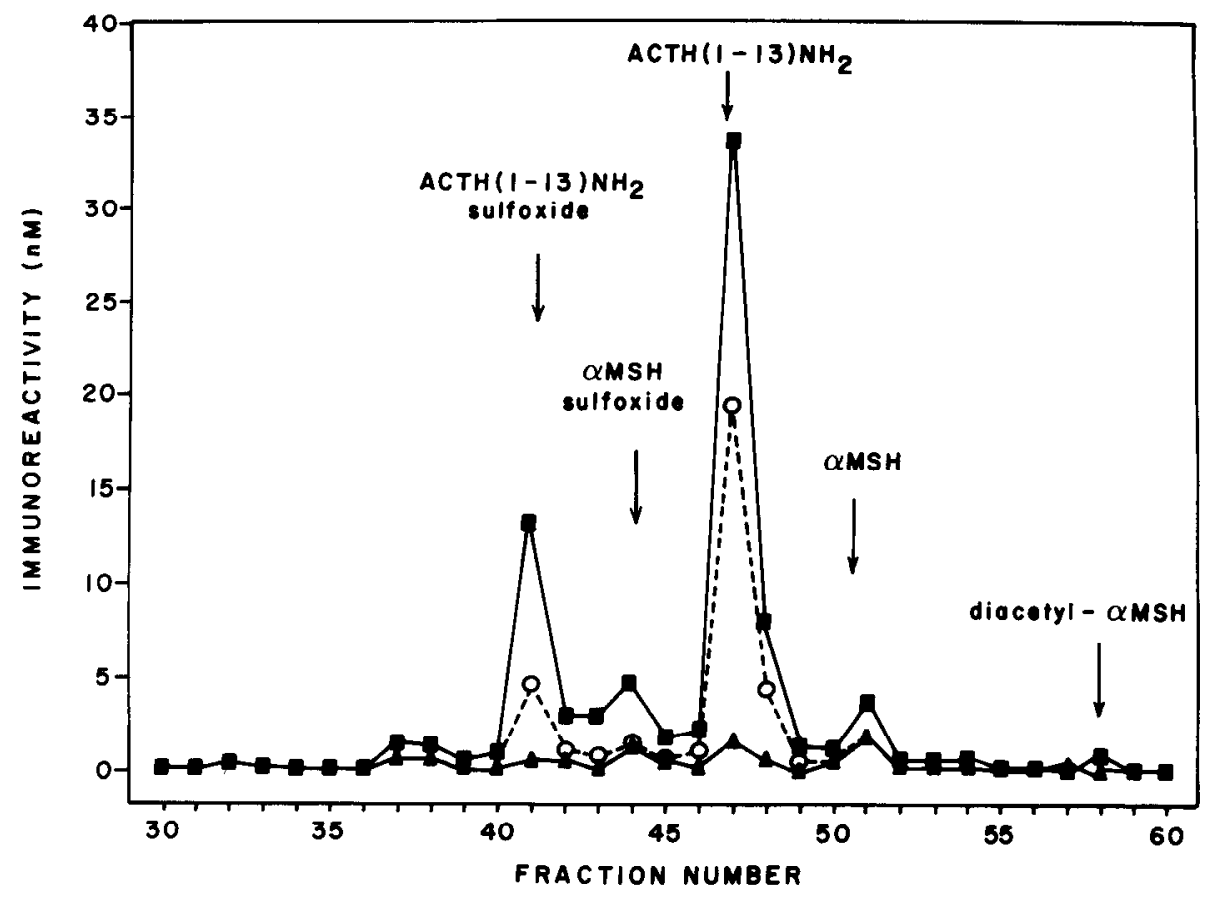




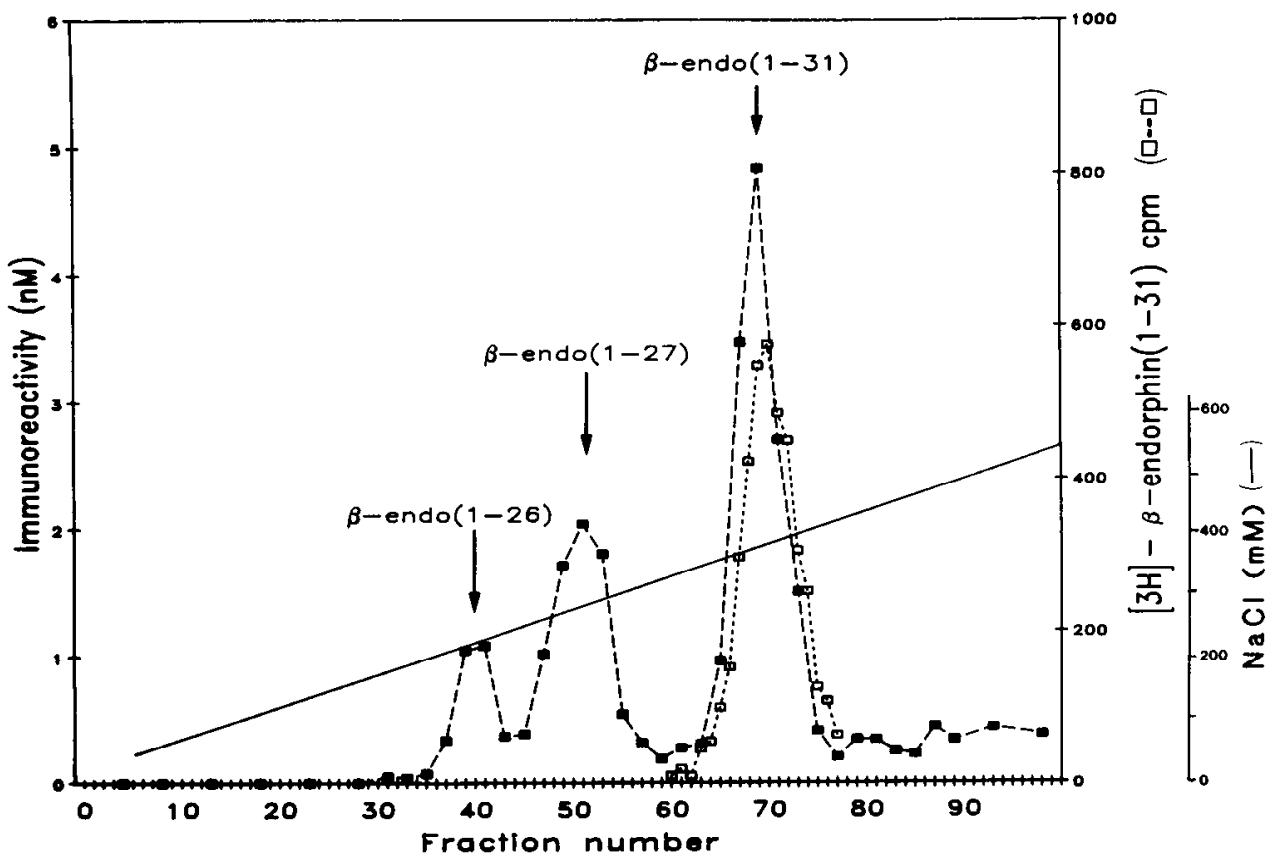

Figure 5. Analysis of $\beta$-endorphin-sized material on SP-Sephadex. A pool of $\beta$-endorphin-sized material from extracts of 38 adult male rat hypothalami $\left(K_{\mathrm{d}} 0.54-0.77\right)$ was dried and resuspended in $50 \%$ acetic acid; ${ }^{3} \mathrm{H}$-Tyr-labeled AtT-20 $\beta$-endorphin( $\left.1-31\right)$ was added $(<0.05$ pmol) and the sample was applied to a SP-Sephadex column $(0.75 \times 20.5 \mathrm{~cm})$. One milliliter fractions were collected (flow rate 9-10 mi/hr). The elution position of the ${ }^{3} \mathrm{H}$-labeled AtT-20 $\beta$-endorphin(1-31) was determined by liquid scintillation counting of $100 \mu \mathrm{l}$ aliquots of each fraction. For immunoassay, aliquots $(30 \mu \mathrm{l})$ were pooled by fives (fractions $1-30$ and fractions $90-100$ ) or pairwise (fractions $31-89$ ). Recoveries of radioactivity and immunoreactivity were 72 and $77 \%$, respectively. Arrows mark the elution positions of $\beta$-endorphin $(1-26)(220 \mathrm{~mm} \mathrm{NaCl}), \beta$-endorphin(127) $(270 \mathrm{mM} \mathrm{NaCl})$, and $\beta$-endorphin(1-31) $(360 \mathrm{~mm} \mathrm{NaCl})$. The elution positions of Ac- $\beta$-endorphin(1-26), Ac- $\beta$-endorphin(1-27), and Ac- $\beta$ endorphin(1-31) correspond to fractions 31, 39, and 61, respectively. $\beta$-Endorphin(1-31), $\beta$-endorphin(1-27), and $\beta$-endorphin(1-26) represented 56,30 , and $11 \%$, respectively, of the total hypothalamic $\beta$-endorphin-related immunoreactive material.

other two antisera. These results suggest that hypothalamic $\alpha$-MSH-sized material is fully $\alpha$-amidated at its carboxyl terminal, whereas only a small percentage of the molecules are $\alpha$ $N$-acetylated.

In order to more fully characterize the $\alpha$-MSH-sized material from rat hypothalamus, the $\alpha$-MSH-sized peptides were analyzed by RP-HPLC in the trifluoroacetic acid/acetonitrile system of Bennett et al. (1981b), which separates $\alpha$-MSH-related molecules primarily by their state of acetylation (Fig. 4). The major immunoreactive $\alpha$-MSH-related peptides werc clutcd with the retention times of $\mathrm{ACTH}(1-13) \mathrm{NH}_{2}$ or its sulfoxide and represented $85 \%$ of the total $\alpha$-MSH-related immunoreactivity. Smaller peaks eluted at the positions of $\alpha$-MSH $[\alpha-N$-acetylACTH(1-13) $\left.\mathrm{NH}_{2}\right]$ and its sulfoxide represented approximately $13 \%$ of the $\alpha$-MSH-related immunoreactive material. Radioimmunoassays of the same fractions with the amide-specific $\alpha-\mathrm{MSH}$ antiserum gave identical results, and assays with the acetylspecific $\alpha$-MSH antiserum further confirmed the identification. In seven separate analyses of $\alpha$-MSH-sized material by RPHPLC, the amount of immunoreactive material corresponding to $\alpha$-MSH or its sulfoxide varied between 3 and $13 \%$ of the total $\alpha$-MSH-related immunoreactivity. The occurrence of substantial amounts of the sulfoxides of both ACTH(1-13) $\mathrm{NH}_{2}$ and $\alpha$ MSH in hypothalamic extracts, rather than representing the actual physical form of these molecules as they exist in hypothalamic tissue, probably results from oxidation during the course of biochemical manipulation.

\section{Characterization of $\beta$-endorphin-sized material}

Zakarian and Smyth (1982a, b) have reported region-specific processing variations of $\beta$-endorphin throughout the CNS, revealing two contrasting patterns of $\alpha-N$-acetylation, which suggest the gradual increase of such acetylation from hypothalamus to midbrain. Weber et al. (1981) have found that less than $2 \%$ of the $\beta$-endorphin-sized immunoreactive material from extracts of normal rat brain was $\alpha-N$-acetylated. The $\beta$-endorphinsized material from rat hypothalamus was characterized by ionexchange chromatography on a column of SP-Sephadex (Fig. 5). A trace amount of ${ }^{3} \mathrm{H}$-labeled $\beta$-endorphin(1-31) obtained from a mouse pituitary corticotropic tumor cell line (AtT-20) was included in each sample to mark the elution position of $\beta$-endorphin( $1-31)$. We detected three peaks of $\beta$-endorphin immunoreactivity with elution positions corresponding to those of $\beta$-endorphin(1-31), $\beta$-endorphin(1-27), and $\beta$-endorphin( $1-$ 26 ) or acetyl- $\beta$-endorphin(1-27) (Fig. 5); the latter two peptides are not resolved by this system. Owing to the absence of significant amounts of the $\alpha$ - $N$-acetylated derivatives of $\beta$-endorphin(1-31) and $\beta$-endorphin(1-26), the earliest-eluted form of $\beta$-endorphin-related material was tentatively identified as $\beta$-endorphin(1-26), rather than acetyl- $\beta$-endorphin(1-27).

In the analysis shown, the $\alpha-N$-acetylated forms of $\beta$-endorphin-primarily acetyl- $\beta$-endorphin $(1-31)$-represented less than $2 \%$ of the total $\beta$-endorphin-related immunoreactivity. In four separate analyses, the amount of $\beta$-endorphin-related immunoreactive material corresponding to the expected elution position of $\alpha$ - $N$-acetyl- $\beta$-endorphin( $1-31)$ varied between 1 and $6 \%$. Full-length $\beta$-endorphin(1-31) (acetylated and not) consistently acounted for about $60 \%$ of the $\beta$-endorphin-sized immunoreactive material, with the remaining $40 \%$ accounted for by material that had undergone carboxyl-terminal proteolytic processing. The extent of carboxyl-terminal proteolysis was somewhat more variable, the ratio of $\beta$-endorphin(1-27) to $\beta$-endorphin(1-26) varying between 1 and 2 .

Although ion-exchange chromatography utilizing SP-Sephadex represents an effective means for separating various $\alpha-N$ acetylated and carboxyl-terminal shortened forms of $\beta$-endorphin, the presence of relatively high concentrations of $\mathrm{NaCl}$ in the column fractions may interfere with subsequent immu- 


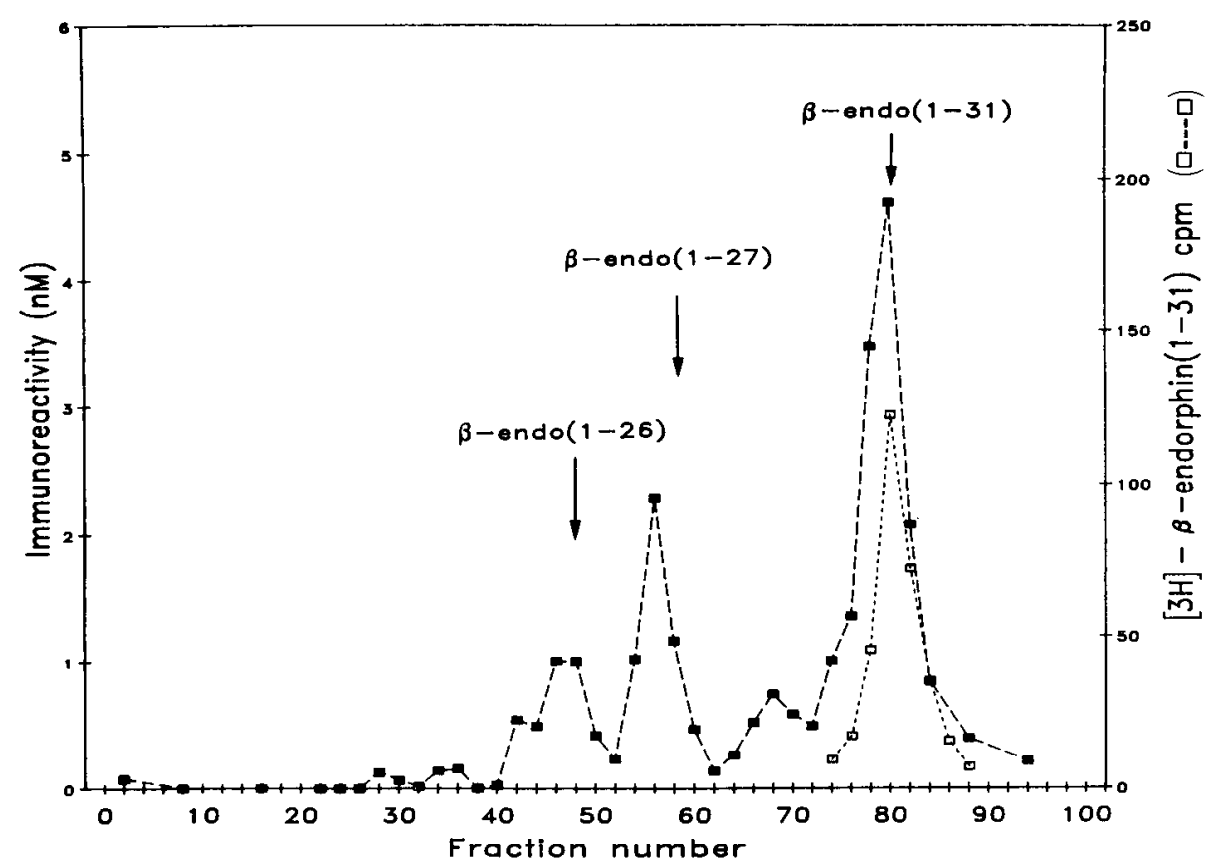

Figure 6. Analysis of $\beta$-endorphin-sized material by ion-exchange (IEX)-HPLC. A pool of $\beta$-endorphin-sized material $\left(K_{\mathrm{d}} 0.58-0.76\right)$ from extracts of 17 adult male rat hypothalami was dried under reduced pressure and resuspended in $10 \mathrm{~mm}$ ammonium formate, $\mathrm{pH} 2.5$, in $30 \%$ acetonitrile; a ${ }^{3} \mathrm{H}$-labeled sample of AtT-20 $\beta$-endorphin(1-31) was added as an internal standard $(<0.05$ pmol). The sample was analyzed by IEX-HPLC as described in Materials and Methods. For immunoassays, aliquots $(100 \mu \mathrm{l})$ of $0.5 \mathrm{ml}$ fractions were pooled by fives (fractions 1-25 and 86-95) or pairwise (fractions 26-85), dried under reduced pressure, and dissolved in $100 \mathrm{~mm}$ sodium phosphate, pH 7.6, containing $1 \%$ Triton X-100. The elution position of the ${ }^{3} \mathrm{H}$-labeled marker was determined by liquid scintillation counting of $50 \mu \mathrm{l}$ aliquots of each fraction. Recovery of radioactivity was $73 \%$. Arrows mark the elution positions of $\beta$-endorphin(1-26), $\beta$-endorphin(1-27), and $\beta$-endorphin(1-31). The elution positions of acetyl- $\beta$ endorphin(1-26), acetyl- $\beta$-endorphin(1-27), and acetyl- $\beta$-endorphin(1-31) correspond to fractions 37,42 , and 68 , respectively. $\beta$-Endorphin(1-31), acetyl- $\beta$-endorphin(1-31), $\beta$-endorphin(1-27), and $\beta$-endorphin(1-26) represented $57,7,19$, and 14\%, respectively, of the total hypothalamic $\beta$ endorphin-related immunoreactive material.

noassay analyses. This problem is particularly evident when attempting to analyze a tissue such as hypothalamus, whose $\beta$-endorphin content is low when compared to the pituitary. Separation of the various forms of $\beta$-endorphin by IEX-HPLC with volatile buffers was investigated as an alternative fractionation method (Fig. 1). Whole hypothalamic extracts or $\beta$-endorphin-sized material were analyzed by ion-exchange HPLC on a cation-exchange column; peptides were eluted from the column with an increasing concentration of ammonium formate, pH 2.5, in 30\% acetonitrile (Fig. 6). Four major peaks of $\beta$-endorphin-related immunoreactivity, corresponding to the elution positions of $\beta$-endorphin(1-31), acetyl- $\beta$-endorphin(1$31), \beta$-endorphin(1-27), and $\beta$-endorphin(1-26), were detected (Fig. 6). Minor peaks corresponded to the clution positions of acetyl- $\beta$-endorphin(1-26) (fraction 37) and acetyl- $\beta$-endorphin(1-27) (fraction 42). Results obtained using IEX-HPLC were consistent with those previously obtained with SP-Sephadex, demonstrating that fully bioactive $\beta$-endorphin( $1-31)$ accounts for more than half of the total hypothalamic $\beta$-endorphin-related immunoreactivity.

\section{Characterization of CLIP-sized material}

Previous studies have demonstrated that approximately twothirds of the CLIP-sized material in the rat intermediate pituitary is phosphorylated at Ser $^{31}$ (Bennett et al., 1982; Browne et al., 1981a; Eipper and Mains, 1982). In order to determine the extent of phosphorylation of the CLIP-related molecules in rat hypothalamus, CLIP-sized material was fractionated by isoelectric focusing (Fig. 7, upper). A trace amount of ${ }^{3} \mathrm{H}$-labeled CLIP obtained from primary cultures of rat neurointermediate lobe was included in each sample as an internal standard. Two peaks of CLIP-related immunoreactivity, which focused with phosphorylated rat CLIP at $\mathrm{pH} 4.12$ and with nonphosphory- lated rat CLIP at $\mathrm{pH} 4.47$, were detected; the theoretical isoelectric focusing points for the phosphorylated and nonphosphorylated forms of rat CLIP are 4.08 and 4.43 , respectively (Eipper and Mains, 1982). The minor peaks of immunoreactivity focusing at $\mathrm{pH} 3.68$ and $\mathrm{pH} 3.05$, which did not correspond to any tritium counts from the pituitary standard, may be due to the presence of glycosylated CLIP in the original G-75 gel filtration pool. Based on the distribution of immunoreactivity in Figure 7 (top), $>90 \%$ of the hypothalamic CLIP-sized material is phosphorylated. In four separate analyses, the extent of phosphorylation of hypothalamic CLIP-sized material varied between 83 and $93 \%$.

Alkaline phosphatase treatment was used to verify the hypothesis that the major difference between the two isoelectric forms of CLIP was the presence of a phosphate residue (Fig. 7, bottom). When hypothalamic CLIP-sized material was treated with alkaline phosphatase before application to the isoelectric focusing gel, a single major peak of CLIP-related immunoreac-

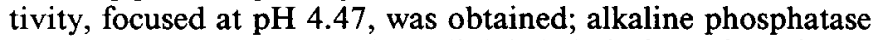
treatment also converted the radiolabeled pituitary CLIP internal standard into a single peak, focusing at $\mathrm{pH} 4.47$. The quantitative conversion of the more acidic form of hypothalamic CLIP to the more basic form by treatment with alkaline phosphatase demonstrates that the major difference between these isoelectric forms is the presence of a phosphate moiety.

In order to confirm the extent of phosphorylation of CLIP in hypothalamic tissue extracts, tryptic digests of control and alkaline phosphatase-treated CLIP-sized material were analyzed as in Figure 7 (data not shown). Approximately $82 \%$ of the CLIP-related immunoreactivity focused at $\mathrm{pH} 3.12$, close to the theoretical isoelectric point for phosphorylated ACTH(22-39) $(p I=3.18)$, with the remainder focusing at $\mathrm{pH} 3.70$, which is near the theoretical isoelectric point for nonphosphorylated 


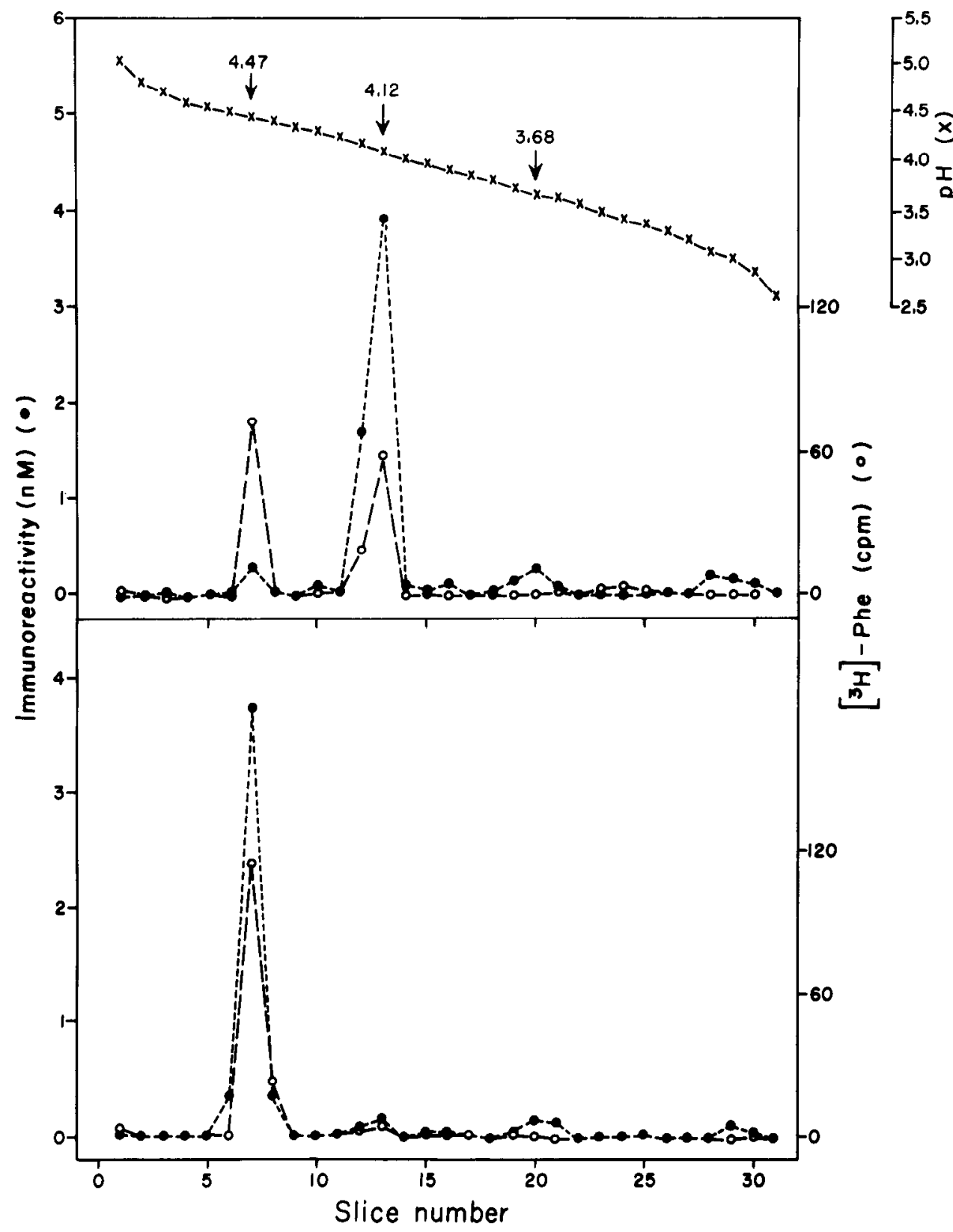

Figure 7. Isoelectric focusing of hypothalamic CLIP-sized immunoreactive material. A pool of CLIP-sized material $\left(K_{d} 0.69-0.79\right)$ from extracts of 48 adult rat hypothalami was dried, resuspended in $0.1 \mathrm{M} \mathrm{NH}_{4} \mathrm{HCO}_{3}$ containing $0.5 \mathrm{mg} / \mathrm{ml} \mathrm{BSA}$; a sample of ${ }^{3} \mathrm{H}$-phenylalanine-labeled CLIP ( $<0.08 \mathrm{pmol}$ ), obtained from primary cultures of rat intermediate pituitary, was added. The sample was then divided into equal aliquots; one aliquot was analyzed directly (top) and the other was digested with alkaline phosphatase before analysis (bottom). The samples were applied to a $2 \mathrm{~mm}$ layer of Sephadex IEF resin $(\mathrm{pH} 2.5-5.0)$ in the region of slice 25 . Samples were eluted from the resin in $2 \mathrm{ml}$ of $25 \mathrm{~mm}$ $\mathrm{NH}_{4} \mathrm{HCO}_{3}, 0.1 \mathrm{mg} / \mathrm{ml} \mathrm{BSA}$, and $0.005 \%$ NP-40. The isoelectric focusing point of the ${ }^{3} \mathrm{H}$-labeled intermediate pituitary CLIP was determined by liquid scintillation counting of $700 \mu \mathrm{l}$ aliquots of each fraction. For immunoassays, samples were dried under reduced pressure and dissolved in $100 \mathrm{~mm}$ sodium phosphate, $\mathrm{pH} 7.6$, containing $1 \%$ Triton $\mathrm{X}$ 100 . Recoveries of immunoreactivity for the control and alkaline phosphatase-treated sample were $99 \%$ and $84 \%$, respcctivcly.
ACTH(22-39) $(p I=3.52)$. Alkaline phosphatasc treatment of the carboxyl-terminal tryptic peptides resulted in a single major peak, focusing at $\mathrm{pH} 3.70$. The results obtained by analysis of intact CLIP or the carboxyl-terminal tryptic peptide of CLIP were in agreement.

\section{Characterization of $\gamma$-LPH-sized material}

Hypothalamic $\gamma$-LPH-sized immunoreactive material was fractionated by isoelectric focusing in order to determine whether it is subjected to additional posttranslational modifications, such as acetylation, phosphorylation, or sulfation, which would affect its isoelectric point (Fig. 8). A single major peak, representing $74 \%$ of the total $\gamma$-LPH-related immunoreactivity, focused at $\mathrm{pH} 4.32$, the theoretical isoelectric focusing point for rat $\gamma-\mathrm{LPH}$ (Eipper and Mains, 1982). A minor peak focusing at $\mathrm{pH} 4.44$, representing approximately $10 \%$ of the total $\gamma$-LPH-related immunoreactivity, could result from the removal of either the carboxyl-terminal aspartic acid or the amino-terminal glutamic acid residues. Addition of an $\alpha-N$-acetyl, phosphate, or sulfate moiety would be expected to shift the isoelectric point of the modified $\gamma$-LPH to approximately 4.17. The majority of the hypothalamic $\gamma$-LPH-sized material is indistinguishable from $\gamma$-LPH isolated from the pars intermedia, and does not appear to be subject to additional posttranslational processing.

\section{Discussion}

Published reports on the ACTH and $\beta$-LPH regions of the proACTH/endorphin precursor indicate that the proteolytic processing pattern in the hypothalamus closely resembles that in the intermediate pituitary (Barnea et al., 1981, 1982; Gramsch et al., 1980; Loh et al., 1980; Orwoll et al., 1978; Seizinger et al., 1984). In the present studies, this similarity was extended to the amino-terminal region of pro-ACTH/endorphin; at the level of gel filtration, material of the size of joining peptide and glycosylated $\gamma_{3}-\mathrm{MSH}$ represented major end products. The major peptide products found in the rat hypothalamus are diagrammed in Figure 9; the cystine-rich amino-terminal region was not investigated in these studies and is therefore not represented. The endoproteolytic processing events that proceed essentially to completion all involve cleavage at a -Lys-Arg- 
Figure 8. Isoelectric focusing of hypothalamic $\gamma$-LPH-sized immunoreactive material. A pool of $\gamma$-LPH-sized material $\left(K_{\mathrm{d}} 0.52-0.62\right)$ from extracts of 18 adult male rat hypothalami was dried under reduced pressure, resuspended in 5 mм acetic acid, and applied to a $1 \mathrm{~mm}$ layer of Sephadex IEF (pH 2.5-5); samples were applied in the region of slice 25. Electrophoresis was allowed to proceed for $19 \mathrm{hr}$ at $600 \mathrm{~V}$ and the bands of resin were eluted in $3 \mathrm{ml}$ of $50 \mathrm{mM} \mathrm{NH}_{4} \mathrm{HCO}_{3}$ containing $1 \mathrm{mg} /$ $\mathrm{ml} \mathrm{BSA}$ and $0.1 \% \mathrm{NP}-40$. For immunoassays, samples were treated as described in Figure 7; recovery of $\gamma-\mathrm{LPH}$ related immunoreactivity was $120 \%$.

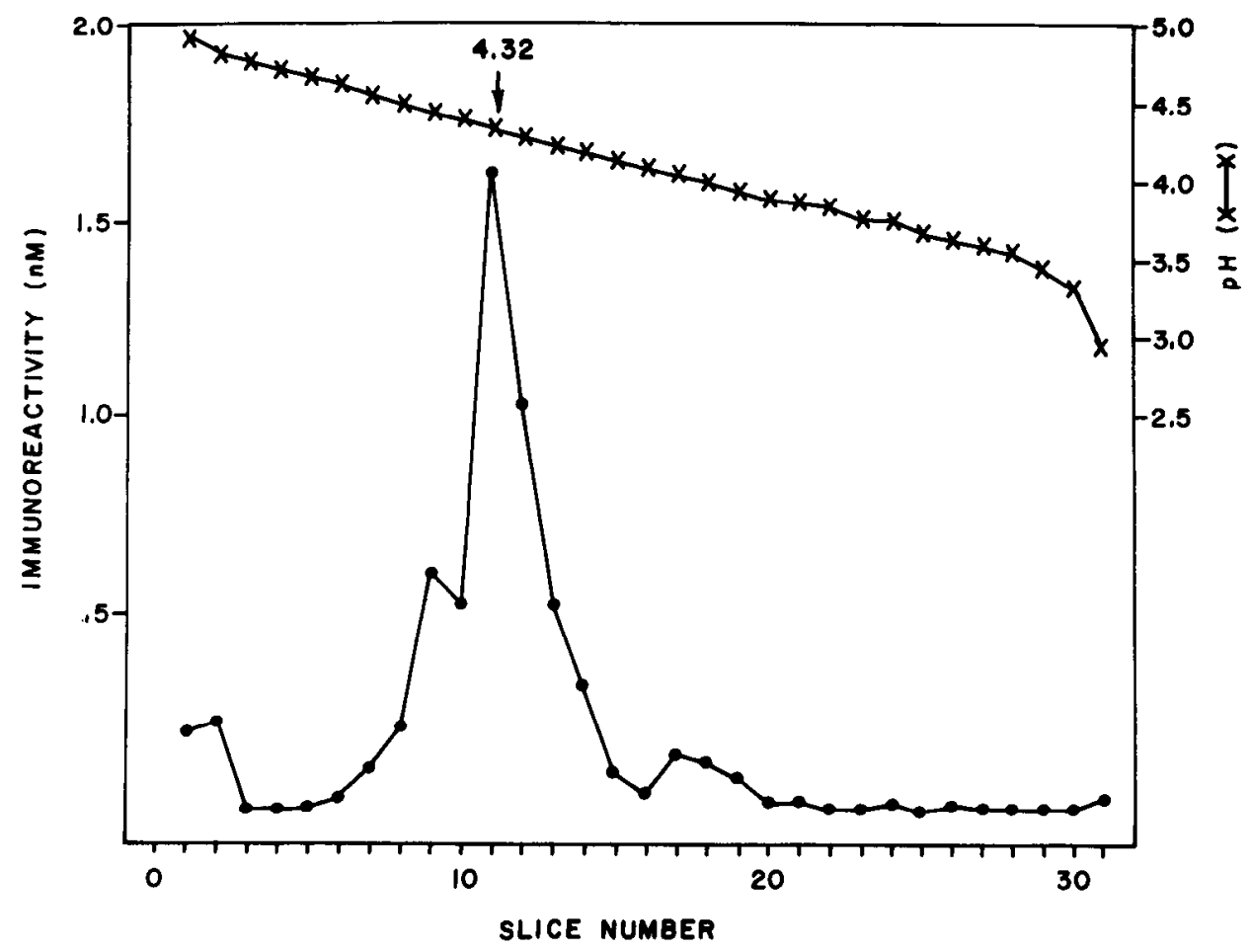

Previous studies have not reached a consensus regarding the extent to which $\alpha$-MSH- and $\beta$-endorphin-related material in extracts of rat hypothalamus or whole brain is $\alpha$ - $N$-acetylated (Loh et al., 1980; O'Donohue et al., 1982). The biochemical analyses presented here demonstrate that about $10 \%$ of both the hypothalamic $\alpha$-MSH- and $\beta$-endorphin-related material represents $\alpha-N$-acetylated material (Figs. 3-6). These results are in agreement with a majority of the previously published works regarding the limited extent to which both $\alpha$-MSH and $\beta$-endorphin are acetylated in the hypothalamus (Evans et al., 1982; Geis et al., 1984; Liotta et al., 1984; Smith et al., 1982; Turner et al., 1983; Weber et al., 1981; Zakarian and Smyth, 1979, $1982 \mathrm{a}, \mathrm{b})$. If, as has been suggested for the intermediate pituitary (Chappell et al., 1982; Glembotski, 1982), a single secretory granule-associated acetyltransferase is responsible for the amino-terminal acetylation of both $\alpha$-MSH and $\beta$-endorphin, parallel alteration in the acetylation of both products would be mechanism for modulating the hormonal or neurosecretory output of neurons expressing the same gene.

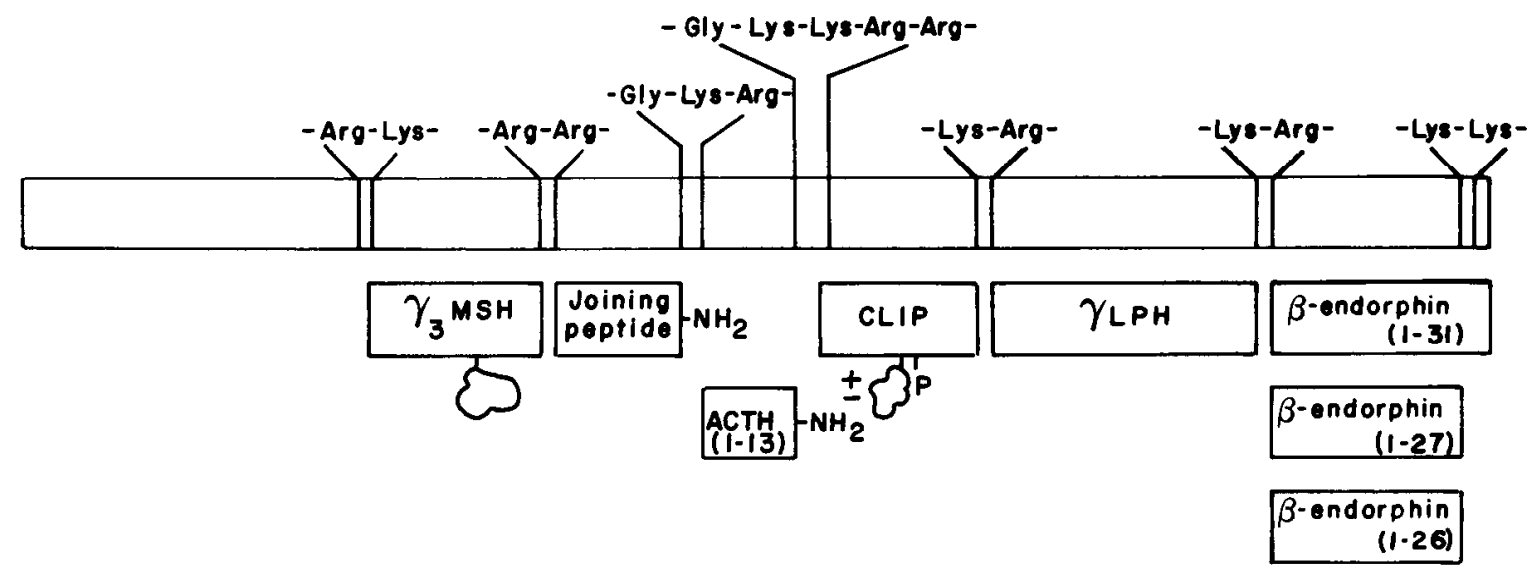

Figure 9. Major products of pro-ACTH/endorphin processing in rat hypothalamus. A schematic diagram of the rat pro-ACTH/endorphin molecule is depicted (Drouin et al., 1980). It shows the major end products of pro-ACTH/endorphin processing in rat hypothalamus. The amino acid sequences at potential paired basic amino acid cleavage sites and at potential amidation sites are designated. The $N$-linked oligosaccharide groups within $\gamma_{3}-\mathrm{MSH}$ and CLIP, the phosphate moiety within CLIP, and the site of cleavage producing the amino terminus of $\gamma_{3}-\mathrm{MSH}$ (Lys $\mathrm{s}_{0}-\gamma_{3}-\mathrm{MSH}$ ) have been positioned by analogy to the pituitary (Bennett et al., 1981a; Browne et al., 1981b; Eipper and Mains, 1977). 
expected. Approximately $80 \%$ of the $\alpha-\mathrm{MSH}$ - and $60 \%$ of the $\beta$-endorphin-related material in extracts of rat or guinea pig caudal medulla, containing the region of the nucleus of the solitary tract, is $\alpha-N$-acetylated (Dores et al., in press). Liotta et al. (1984), using in vivo labeling, reported production of only nonacetylated forms of both $\alpha$-MSH and $\beta$-endorphin by neurons in the region of the arcuate nucleus. These two observations suggest that the $\alpha-N$-acetyl-ACTH(1-13) $\mathrm{NH}_{2}$ and $\alpha-N$-acetylated $\beta$-endorphin in the hypothalamic region may be present in nerve fibers or terminal fields originating in the nucleus tractus solitarius. Alternatively, a subpopulation of ACTH/endorphin arcuate neurons projecting to specific target areas may contain peptide products different from those elaborated by the majority.

Limited carboxyl-terminal proteolysis of $\beta$-endorphin(1-31) has pronounced effects on opiate activity (Geisow et al., 1977; Hammonds et al., 1984; Smyth et al., 1979). In opiate bioassays, $\beta$-endorphin $(1-27)$ has been shown to be approximately equipotent to $\beta$-endorphin(1-31) in inhibiting the contraction of guinea pig myenteric plexus (McKnight et al., 1983). In the CNS, the analgesic potency of $\beta$-endorphin(1-27) is only $2 \%$ that of $\beta$-endorphin( $1-31)$, but this decreased opiate bioactivity is only partially reflected in a decreased affinity for opiate receptors and makes $\beta$-endorphin( $1-27)$ a potent antagonist of $\beta$-endorphin( 1 31) (Hammonds et al., 1984).

The results presented here are in agreement with previous studies demonstrating that $\beta$-endorphin(1-31) represents the predominant end product in the hypothalamus (Dennis et al., 1983a; Liotta et al., 1984; Zakarian and Smyth, 1979, 1982a, b). Ion exchange chromatography (Figs. 5 and 6 ) has demonstrated that, in addition to $\beta$-endorphin(1-31), $\beta$-endorphin( $1-27)$ and $\beta$-endorphin(1-26) represent significant end products. The results of in vivo biosynthetic labeling studies suggested that only intact $\beta$-endorphin(1-31) was a major product peptide of arcuate ACTH/endorphin neurons (Liotta et al., 1984); however, assuming that the kinetics of carboxyl-terminal shortening are comparable in hypothalamus and pars intermedia, the labeling period studied by Liotta et al. (1984) would not have been sufficient to determine the final extent of carboxyl-terminal proteolytic processing of $\beta$-endorphin (Glembotski, 1982). As with $\alpha-N$-acetylation of $\beta$-endorphin, the degree to which the carboxyl-terminally shortened forms of $\beta$-endorphin are produced may represent one of the regulatory mechanisms by which normal levels of opiate activity are maintaincd within the CNS.

The phosphorylation of corticotropin-related peptides has been shown to vary widely among species and also among tissues within a given species; one-fifth of the mouse pituitary ACTH and CLIP, one-third of the human pituitary ACTH, one-half of rat antcrior pituitary ACTH, and two-thirds of rat intermediate pituitary CLIP are phosphorylated (Bennett et al., 1982; Eipper and Mains, 1982; Mains and Eipper, 1983). Isoelectric focusing analyses have demonstrated that 83 to $93 \%$ of rat hypothalamic CLIP-sized immunoreactive material is phosphorylated (Fig. 7). Glycosylation of corticotropin-related peptides has also been shown to be species-specific; whereas approximately two-thirds of the corticotropin-related peptides in the mouse pituitary are glycosylated, only one-sixth are glycosylated in the rat (Bennett et al., 1982; Eipper and Mains, 1982). The present study demonstrates that approximately $20 \%$ of the hypothalamic carboxylterminal ACTH-related immunoreactivity corresponds to the molecular weight of glycosylated CLIP (Fig. 2, middle), the same percentage found in rat intermediate pituitary (Bennett et al., 1982; Eipper and Mains, 1982). The physiological consequences of such limited glycosylation and extensive phosphorylation remain to be determined. Equimolar amounts of CLIP-related molecules and other pro-ACTH/endorphin-derived peptides were found in the hypothalamus (Fig. 2, middle). Although the carboxyl-terminal ACTH antiserum used in these analyses does not cross-react with ACTH(18-38)-related molecules, this result suggests that carboxyl-terminally shortened CLIP does not represent a major hypothalamic product.

As summarized in Figure 9, the differences in the processing patterns in the intermediate pituitary and the hypothalamus might be explained by differences in only three enzymatic activities involved in posttranslational processing. Hypothalamic ACTH/endorphin neurons, similar to intermediate pituitary melanotropes at the level of gross proteolytic processing, appear more like anterior pituitary corticotropes in exhibiting relatively little $\alpha-N$-acetylation of $\alpha$-MSH and $\beta$-endorphin. Carboxylterminal proteolysis of $\beta$-endorphin, which does not occur to any significant extent in corticotropes, occurs to a lesser extent in hypothalamic neurons than in melanotropes. In addition, the hypothalamic neurons exhibit more extensive phosphorylation of CLIP than is observed in either melanotropes or corticotropes. The fact that nearly equimolar amounts of $\beta$-endorphin-, $\gamma$-LPH-, $\alpha$-MSH-, CLIP-, and joining peptide-related immunoreactivity are found in the hypothalamus, and that such molecules have been localized to the same secretory granules (Barnea et al., 1981; Pelletier, 1979), indicates that significant amounts of each of the various product peptides are secreted together in response to appropriate stimuli, and that the coordinate effects of the various peptides on the same and different target neurons must be considered.

\section{References}

Akil, H., W. A. Hewlett, J. D. Barchas, and C. H. Li (1980) Binding of ${ }^{3} \mathrm{H}$-beta-endorphin to rat brain membranes: Characterization of opiate properties and interaction with ACTH. Eur. J. Pharmacol. 64: $1-8$.

Akil, H., Y. Ueda, H. L. Lin, and S. J. Watson (1981) A sensitive coupled HPLC/RIA technique for the separation of endorphins: Multiple forms of $\beta$-endorphin in rat pituitary intermediate vs. anterior lobe. Neuropeptides 1: 429-446.

Barnea, A., G. Cho, and J. C. Porter (1981) Apparent coquestration of immunoreactive corticotropin, $\alpha$-melanotropin and $\gamma$-lipotropin in hypothalamic granules. J. Neurochem. 36: 1083-1092.

Barnea, A., G. Cho, and J. C. Porter (1982) Molecular-weight profiles of immunoreactive corticotropin in the hypothalamus of the aging rat. Brain Res. 232: 355-363.

Bennett, H. P. J., A. M. Hudson, L. Kelly, C. McMartin, and G. E. Purdon (1978) A rapid method, using octadecasilyl-silica, for the extraction of certain peptides from tissues. Biochem. J. 175: 11391141.

Bennett, H. P. J., C. A. Browne, and S. Solomon (1981a) Biosynthesis of phosphorylated forms of corticotropin-related peptides. Proc. Natl. Acad. Sci. USA 78: 4713-4717.

Bennett, H. P. J., C. A. Browne, and S. Solomon (1981b) Complete purification of pituitary peptides using reversed-phase HPLC alone. In Peptides, D. H. Rich and E. Gross, eds., pp. 785-788, Pierce Chemical Co., Rockford, IL.

Bennett, H. P. J., C. A. Browne, and S. Solomon (1982) Characterization of eight forms of corticotropin-like intermediary lobe peptide from the rat intermediary pituitary. J. Biol. Chem. 257: 10,09610,102 .

Bennett, H. P., C. A. Browne, and S. Solomon (1983) Alpha- $N$-acetyl$\beta$-endorphin(1-26) from the neurointermediary lobe of the rat pituitary: Isolation, purification and characterization by high-performance liquid chromatography. Anal. Biochem. 128: 121-129.

Bloom, F. E., E. L. F. Battenberg, T. Shibasaki, R. Benoit, N. Ling, and R. Guillemin (1980) Localization of $\gamma$-melanocyte-stimulating hormone $(\gamma-\mathrm{MSH})$ immunoreactivity in rat brain and pituitary. Reg. Peptides 1: 205-222.

Browne, C. A., H. P. J. Bennett, and S. Solomon (1981a) Isolation and characterization of corticotropin- and melanotropin-related peptides from neurointermediate lobe of rat pituitary by reversed-phase liquid chromatography. Biochemistry 20:4530-4537.

Browne, C. A., H. P. J. Bennett, and S. Solomon (1981b) The isolation and characterization of $\gamma_{3}$-melanotropin from the neurointermediary lobe of the rat pituitary. Biochem. Biophys. Res. Commun. 100: 336343. 
Chang, A. C. Y., M. Cochet, and S. N. Cohen (1980) Structural organization of human genomic DNA encoding the pro-opiomelanocortin peptide. Proc. Natl. Acad. Sci. USA 77: 4890-4894.

Chappell, M. C., Y. P. Loh, and T. L. O'Donohue (1982) Evidence for an opiomelanotropin acetyltransferase in the rat pituitary neurointermediate lobe. Peptides 3: 405-410.

Dennis, M., C. Lazure, N. G. Seidah, and M. Chretien (1983a) Characterization of $\beta$-endorphin immunoreactive peptides in rat pituitary and brain by coupled gel and reversed-phase high-performance liquid chromatography. J. Chromatogr. 226: 163-172.

Dennis, M., N. G. Seidah, and M. Chretien (1983b) Regional heterogeneity in the processing of pro-opiomelanocortin in rat brain. Life Sci. (Suppl. 1) 33: 49-52.

Dores, R. M., M. Jain, and A. Akil (in press) Characterization of the forms of beta-endorphin and alpha-MSH in the caudal medulla of the rat and guinea pig. Brain Res.

Douglass, J., O. Civelli, and E. Herbert (1984) Polyprotein gene expression: Generation of diversity of neuroendocrine peptides. Annu. Rev. Biochem. 53: 665-715.

Drouin, J., and H. M. Goodman (1980) Most of the coding region of rat ACTH $\beta$-LPH precursor gene lacks intervening sequences. Nature 288: 610-612.

Drouin, J., P. Burbach, J. Charron, and J. P. Gagner (1983) Expression of the pro-opiomelanocortin (POMC) gene. J. Cell. Biochem. (Suppl.) 7A: 107.

Eipper, B. A., and R. E. Mains (1977) Peptide analysis of a glycoprotein form of adrenocorticotropic hormone. J. Biol. Chem. 252: 88218832.

Eipper, B. A., and R. E. Mains (1979) Characterization of mouse tumor cell $\beta$-lipotropin. J. Biol. Chem. 254: 10190-10199.

Eipper, B. A., and R. E. Mains (1980) Structure and biosynthesis of pro-adrenocorticotropin/endorphin and related peptides. Endocrine Rev. 1: 1-27

Eipper, B. A., and R. E. Mains (1981) Further analysis of post-translational processing of $\beta$-endorphin in rat intermediate pituitary. $J$. Biol. Chem. 256: 5689-5695.

Eipper, B. A., and R. E. Mains (1982) Phosphorylation of pro-adrenocorticotropin/endorphin-derived peptides. J. Biol. Chem. 257: 49074915.

Eipper, B. A., C. C. Glembotski, and R. E. Mains (1983) Selective loss of $\alpha$-melanotropin-amidating activity in primary cultures of rat intermediate pituitary cells. J. Biol. Chem. 258: 7292-7298.

Evans, C. J., R. Lorenz, E. Weber, and J. D. Barchas (1982) Variants of alpha-melanocyte stimulating hormone in rat brain and pituitary: Evidence that acetylated $\alpha$-MSH exists only in the intermediate lobe of the pituitary. Biochem. Biophys. Res. Commun. 106: 910-919.

Farese, R. V., N. C. Ling, M. A. Sabir, R. E. Larson, and W. L. Trudeau III (1983) Comparison of the effects of adrenocorticotropin and Lys$\gamma_{3}$-melanocyte-stimulating hormone on steroidogenesis, adenosine $3^{\prime}, 5^{\prime}$-monophosphate production and phospholipid metabolism in rat adrenal facsiculata-reticularis cells in vitro. Endocrinology 112: 129132.

Geis, R., R. Martin, and K. H. Voigt (1984) $\alpha$-MSH-like peptides from the rat hypothalamus and pituitary: Differences in the degree of $N$-acetylation. Horm. Metabol. Res. 16: 266-267.

Geisow, M. J., J. F. W. Deakin, J. O. Dostrovsky, and D. G. Smyth (1977) Analgesic activity of lipotropin C fragment depends on carboxyl terminal tetrapeptide. Nature 269: 167-168.

Glembotski, C. C. (1982) Acetylation of $\alpha$-melanotropin and $\beta$-endorphin in the rat intermediate pituitary. J. Biol. Chem. 257: 10,49310,500 .

Gramsch, C., G. Kleber, V. Hollt, A. Pasi, P. Mehraiein, and A. Herz (1980) Pro-opiocortin fragments in human and rat brain: $\beta$-Endorphin and $\alpha$-melanotropin are the predominant peptides. Brain Res. 192: 109-119.

Guttmann, St., and R. A. Boissonnas (1961) Influence of the structure of the $N$-terminal extremity of $\alpha$-MSH on the melanophore stimulating activity of this hormone. Experientia 17: 265-267.

Hammonds, R. G., Jr., P. Nicolas, and C. H. Li (1984) $\beta$-Endorphin(1$27)$ is an antagonist of $\beta$-endorphin analgesia. Proc. Natl. Acad. Sci. USA 81: 1389-1390.

Houghton, R. A., and C. H. Li (1979) Reduction of sulfoxides in peptides and proteins. Anal. Biochem. 98: 36-49.

Joseph, S. A. (1980) Immunoreactive adrenocorticotropin in rat brain:
A neuroanatomical study using antiserum generated against synthetic ACTH(1-39). Am. J. Anat. 158: 533-548.

Keutmann, H. T., B. A. Eipper, and R. E. Mains (1979) Partial characterization of a glycoprotein comprising the $\mathrm{NH}_{2}$-terminal region of mouse tumor cell pro-adrenocorticotropic hormone/endorphin. J. Biol. Chem. 254: 9204-9208.

Keutmann, H. T., G. W. Lampman, R. E. Mains, and B. A. Eipper (1981) Primary sequence of two regions of mouse pro-adrenocorticotropin/endorphin. Biochemistry 20:4148-4155.

Khachaturian, H., N. E. Alessi, N. Munfakh, and S. J. Watson (1983) Ontogeny of opioid and related peptides in the rat CNS and pituitary: An immunocytochemical study. Life Sci. 33: 61-64.

Krieger, D. T., A. S. Liotta, and E. A. Zimmerman (1980) ACTH, $\beta$-lipotropin and related peptides in brain pituitary and blood. Rec. Prog. Horm. Res. 36: 277-344.

Li, C. H., and D. Chung (1976) Isolation and structure of an untriakonta-peptide with opiate activity from camel pituitary glands. Proc. Natl. Acad. Sci. USA 73: 1145-1148.

Liotta, A. S., and D. T. Krieger (1983a) Proopiomelanocortin (POMC) related peptides in rat brain differ in covalent modification from those in the pars intermedia (PI). Endocrinology (Suppl.) 112: 92.

Liotta, A. S., and D. T. Krieger (1983b) Pro-opiomelanocortin-related and other pituitary hormones in the central nervous system. In Brain Peptides. D. T. Krieger, J. B. Martin, and M. Brownstein, eds., pp. 613-660, Wiley, New York

Liotta, A. S., J. P. Advis, J. E. Krause, J. F. McKelvy, and D. T. Krieger (1984) Demonstration of in vivo synthesis of pro-opiomelanocortin, $\beta$-endorphin, and $\alpha$-melanotropin-like species in the adult rat brain. J. Neurosci. 4: 956-965.

Liston, D., and J. Rossier (1984) Synenkephalin is coreleased with metenkephalin from neuronal terminals in vitro. Neurosci. Lett. 48 . 211-216.

Loh, Y. P., R. L. Eskay, and M. Brownstein (1980) $\alpha$-MSH-like peptides in rat brain: Identification and changes in level during development. Biochem. Biophys. Res. Commun. 94: 916-923.

Mains, R. E., and B. A. Eipper (1979) Synthesis and secretion of corticotropins, melanotropins and endorphins by rat intermediate pituitary cells. J. Biol. Chem. 254: 7885-7894.

Mains, R. E., and B. A. Eipper (1981) Differences in the post-translational processing of $\beta$-endorphin in rat anterior and intermediate pituitary. J. Biol. Chem. 256: 5683-5688.

Mains, R. E., and B. A. Eipper (1983) Phosphorylation of rat and human adrenocorticotropin-related peptides: Physiological regulation and studies of secretion. Endocrinology 112: 1986-1995.

McKnight, A. T., A. D. Corbett, and H. W. Kosterlitz (1983) Increase in potencies of opioid peptides after peptidase inhibition. Eur. $\mathbf{J}$ Pharmacol. 86: 393-402.

Nakanishi, S., A. Inoue, T. Kita, M. Nakamura, A. C. Y. Chang, S. N. Cohen, and S. Numa (1979) Nucleotide sequence of cloned cDNA for bovine corticotropin- $\beta$-lipotropin precursor. Nature 278: $423-$ 427.

O'Donohue, T. L., G. E. Handelmann, T. Chaconas, R. L. Miller, and D. M. Jacobowitz (1981) Evidence that $N$-acetylation regulates the behavioral activity of $\alpha$-MSH in the rat and human central nervous system. Peptides 2: 333-344.

O'Donohue, T. L., G. E. Handelmann, R. L. Miller, and D. M. Jacobowitz (1982) $N$-acetylation regulates the behavioral activity of $\alpha$ melanotropin in a multineurotransmitter neuron. Science 215: 11251127.

Oliver, C., and J. C. Porter (1978) Distribution and characterization of $\alpha$-melanocyte stimulating hormone in rat brain. Endocrinology 102: $697-705$.

Orwoll, E., J. W. Kendall, L. Lamorena, and R. McGilvra (1979) Adrenocorticotropin and melanocyte-stimulating hormone in the brain. Endocrinology 104: 1845-1852.

Pedersen, R. C., A. C. Brownie, and N. Ling (1980) Pro-adrenocorticotropin/endorphin-derived peptides: Coordinate action on adrenal steroidogenesis. Science 208: 1044-1046.

Pelletier, G. (1979) Ultrastructural immunohistochemical localization of adrenocorticotropin and $\beta$-lipotropin in the rat brain. J. Histochem. Cytochem. 27: 1046-1048.

Romagnano, M. A., and S. A. Joseph (1983) Immunocytochemical localization of ACTH(1-39) in the brainstem of the rat. Brain Res. 276: $1-16$. 
Rudman, D., R. K. Chawla, and B. M. Hollins (1979) N,Odiacetylserine $_{1} \alpha$-melanocyte-stimulating hormone, a naturally occurring melanotropic peptide. J. Biol. Chem. 254: 10102-10108.

Scheller, R. H., R. R. Kaldany, T. Kreiner, A. C. Mahon, J. R. Nambu, M. Schaefer, and R. Taussig (1984) Neuropeptides: Mediators of behavior in Aplysia. Science 225: 1300-1308.

Schwartzberg, D. G., and P. K. Nakane (1982) Ontogenesis of adrenocorticotropin-related peptide determinants in the hypothalamus and pituitary gland of the rat. Endocrinology 110: 855-864.

Schwartzberg, D. G., and P. K. Nakane (1983) ACTH-related peptide containing neurons within the medulla oblongata of the rat. Brain Res. 276: 351-356.

Seger, M. A., and H. P. J. Bennett (1984) The N-terminal fragment (NTF) of pro-opiomelanocortin (POMC)-structural and biosynthetic studies. VII Int. Congr. Endocrinol. Abstr.: 1228.

Seidah, N. G., and M. Chretien (1981) Complete amino acid sequence of a human pituitary glycopeptide: An important maturation product of pro-opiomelanocortin. Proc. Natl. Acad. Sci. USA 78: 4236-4240.

Seidah, N. G., J. Rochemont, J. Hamelin, S. Benjannet, and M. Chretien (1981) The missing fragment of the pro-sequence of human proopiomelanocortin: Sequence and evidence for C-terminal amidation. Biochem. Biophys. Res. Commun. 102: 710-716.

Seizinger, B. R., C. Grimm, and A. Herz (1984) Evidence for a differential postnatal development of proenkephalin B (=prodynorphin)derived opioid peptides in the rat hypothalamus. Endocrinology 115 : 926-935.

Smith, A. I., A. B. Keith, J. A. Edwardson, J. A. Biggins, and J. R. McDermott (1982) Characterization of corticotropin-like immunoreactive peptides in rat brain using high performance liquid chromatography. Neurosci. Lett. 30: 133-138.
Smyth, D. G., D. E. Massey, S. Zakarian, and M. Finnie (1979) Endorphins are stored in biologically active and inactive forms: Isolation of $\alpha-N$-acetyl peptides. Nature 279: 252-254.

Tager, H. S., A. H. Rubenstein, and D. F. Steiner (1975) Methods for the assessment of peptide precursors. Studies on insulin biosynthesis. Methods Enzymol. 37: 326-345.

Turner, J. D., A. B. Keith, A. I. Smith, J. R. McDermott, J. A. Biggins, and J. A. Edwardson (1983) Studies on the characterization of $\alpha$-MSH-like immunoreactivity in rat hypothalamus. Reg. Peptides 5 ; 283-293.

Walker, J. M., H. Akil, and S. J. Watson (1980) Evidence for homologous actions of pro-opiocortin products. Scicnce 210: 12471249 .

Watson, S. J., C. W. Richard III, and J. D. Barchas (1978) Adrenocorticotropin in rat brain: Immunocytochemical localization in cells and axons. Science 200: 1180-1182.

Weber, E., C. J. Evans, and J. D. Barchas (1981) Acetylated and nonacetylated forms of $\beta$-endorphin in rat brain and pituitary. Biochem. Biophys. Res. Commun. 103: 982-989.

Zakarian, S., and D. G. Smyth (1979) Distribution of active and inactive forms of endorphins in rat pituitary and brain. Proc. Natl. Acad. Sci. USA 76: 5972-5976.

Zakarian, S., and D. G. Smyth (1982a) Distribution of $\beta$-endorphinrelated peptides in rat pituitary and brain. Biochem. J. 202: 561-571.

Zakarian, S., and D. G. Smyth (1982b) $\beta$-Endorphin is processed differently in specific regions of rat pituitary and brain. Naturc 296: 250-252.

Zimmerman, E. A., A. Liotta, and D. T. Krieger (1978) $\beta$-Lipotropin in brain: Localization of hypothalamic neurons by immunoperoxidase technique. Cell Tiss. Res. 186: 393-398. 